Atmos. Chem. Phys., 13, 9641-9660, 2013

www.atmos-chem-phys.net/13/9641/2013/

doi:10.5194/acp-13-9641-2013

(c) Author(s) 2013. CC Attribution 3.0 License.

\title{
On the uses of a new linear scheme for stratospheric methane in global models: water source, transport tracer and radiative forcing
}

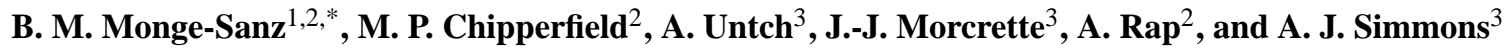 \\ ${ }^{1}$ Royal Netherlands Meteorological Institute, De Bilt, the Netherlands \\ ${ }^{2}$ Institute for Climate and Atmospheric Science, School of Earth and Environment, University of Leeds, UK \\ ${ }^{3}$ European Centre for Medium-Range Weather Forecasts, Reading, UK \\ *now at: European Centre for Medium-Range Weather Forecasts, Reading, UK
}

Correspondence to: B. M. Monge-Sanz (beatriz@env.leeds.ac.uk)

Received: 10 October 2011 - Published in Atmos. Chem. Phys. Discuss.: 6 January 2012

Revised: 31 July 2013 - Accepted: 5 August 2013 - Published: 30 September 2013

\begin{abstract}
This study evaluates effects and applications of a new linear parameterisation for stratospheric methane and water vapour. The new scheme (CoMeCAT) is derived from a 3-D full-chemistry-transport model (CTM). It is suitable for any global model, and is shown here to produce realistic profiles in the TOMCAT/SLIMCAT 3-D CTM and the ECMWF (European Centre for Medium-Range Weather Forecasts) general circulation model (GCM). Results from the new scheme are in good agreement with the full-chemistry CTM $\mathrm{CH}_{4}$ field and with observations from the Halogen Occultation Experiment (HALOE). The scheme is also used to derive stratospheric water increments, which in the CTM produce vertical and latitudinal $\mathrm{H}_{2} \mathrm{O}$ variations in fair agreement with satellite observations. Stratospheric $\mathrm{H}_{2} \mathrm{O}$ distributions in the ECMWF GCM show realistic overall features, although concentrations are smaller than in the CTM run (up to $0.5 \mathrm{ppmv}$ smaller above $10 \mathrm{hPa}$ ). The potential of the new CoMeCAT tracer for evaluating stratospheric transport is exploited to assess the impacts of nudging the free-running GCM to ERA40 and ERA-Interim reanalyses. The nudged GCM shows similar transport patterns to the offline CTM forced by the corresponding reanalysis data. The new scheme also impacts radiation and temperature in the model. Compared to the default $\mathrm{CH}_{4}$ climatology and $\mathrm{H}_{2} \mathrm{O}$ used by the ECMWF radiation scheme, the main effect on ECMWF temperatures when considering both $\mathrm{CH}_{4}$ and $\mathrm{H}_{2} \mathrm{O}$ from CoMeCAT is a decrease of up to $1.0 \mathrm{~K}$ over the tropical mid/low stratosphere. The effect of using the CoMeCAT scheme for radiative forcing (RF) calculations is investigated using the offline Edwards-Slingo radiative transfer model. Compared to the
\end{abstract}

default model option of a tropospheric global 3- $\mathrm{D} \mathrm{CH}_{4}$ value, the CoMeCAT distribution produces an overall change in the annual mean net RF of up to $-30 \mathrm{~mW} \mathrm{~m}^{-2}$.

\section{Introduction}

The stratosphere is being increasingly acknowledged as one of the keys to adding more skill to numerical models in a wide range of timescales and applications, from weather forecasts to climate studies, as well as a potential source of seasonal meteorological predictability (Solomon et al., 2010; Maycock et al., 2011; Scaife et al., 2012). To capture the variability of the stratosphere, radiative processes in this region need to be realistically modelled. Stratospheric radiative heating rates strongly depend on the distribution of concentrations of radiatively active gases in this region. Therefore, numerical models that consider the stratosphere but do not fully treat its stratospheric chemistry need realistic stratospheric descriptions of, at least, the main greenhouse gases (GHGs), i.e. $\mathrm{O}_{3}, \mathrm{H}_{2} \mathrm{O}, \mathrm{CH}_{4}$ and chlorofluorocarbons (CFCs).

In the past more attention was paid to the description of stratospheric $\mathrm{O}_{3}$ in models; for example, the European Centre for Medium-Range Weather Forecasts (ECMWF) first included their current $\mathrm{O}_{3}$ parameterisation (Cariolle and Déqué, 1986; Cariolle and Teyssèdre, 2007) to improve the use of satellite radiance data by providing the radiance observation operators with accurate 3-D ozone fields instead of a climatology (Dethof and Hólm, 2004). This showed that including one of the main stratospheric radiative gases in 
the model had the potential to improve the assimilation of satellite radiances, with subsequent benefits for numerical weather prediction and reanalysis production.

However, the description of stratospheric $\mathrm{CH}_{4}$ and $\mathrm{H}_{2} \mathrm{O}$ is still too simple in numerical weather prediction models (NWP) such as the ECMWF model (e.g. Bechtold et al., 2009). The shortcomings of $\mathrm{H}_{2} \mathrm{O}$ descriptions in the stratosphere are not exclusive to NWP models, Solomon et al. (2010) note that most global climate models also show limitations in their representation of stratospheric $\mathrm{H}_{2} \mathrm{O}$. As discussed by Gettelman et al. (2010), even if the ability to simulate stratospheric $\mathrm{H}_{2} \mathrm{O}$ has improved significantly in recent years, there are still discrepancies between models, the annual cycle in the lower stratosphere is not captured by all models, and there are still some models that consider $\mathrm{H}_{2} \mathrm{O}$ to be fixed throughout the stratosphere.

Better descriptions of stratospheric water vapour in models are expected to have a positive impact not only on temperature and wind fields, but also on the stratospheric BrewerDobson circulation and on tropospheric climate and trends (e.g. Solomon et al., 2010; Maycock et al., 2013). The distribution of radiatively active gases in the stratosphere is receiving increasing attention due to its relevance for climate studies through the interaction with radiation and temperature. Nevertheless, uncertainties remain in current models regarding key atmospheric transport processes controlling these gases' distribution and evolution (e.g. Solomon et al., 2010; Ravishankara, 2012; Riese et al., 2012). Improved stratospheric descriptions are, therefore, of interest for models, such as the ECMWF Integrated Forecast System (IFS), which are not only used for short/medium-term weather prediction but also form the basis for seasonal prediction systems, long reanalyses production systems and Earth system models like EC-Earth (Hazeleger et al., 2010). Improving the description of the stratosphere is becoming especially important if NWP models want to evolve towards seamless prediction systems (e.g. Palmer et al., 2008).

Stratospheric $\mathrm{H}_{2} \mathrm{O}$ simulations within 3-D global models are problematic due to the variety of processes involved: humidity entry rate through the tropical tropopause layer (TTL), oxidation of $\mathrm{CH}_{4}$ in the stratosphere, mesospheric photolysis, transport and mixing within the stratosphere and exchange processes through the tropopause. In addition, feedbacks exist between all these factors, e.g. radiation, stratospheric circulation and tropical tropopause temperatures. Implementing a stratospheric $\mathrm{H}_{2} \mathrm{O}$ parameterisation simple enough for forecasting purposes, while considering all the relevant processes in an accurate way, should at least incorporate realistic $\mathrm{CH}_{4}$ oxidation and allow for feedbacks with atmospheric temperatures. One of the current problems is the poor representation of $\mathrm{CH}_{4}$ found in most general circulation models (GCMs) which, in spite of being a major GHG, is often represented simply as a globally averaged value or a climatology. A realistic representation of stratospheric $\mathrm{CH}_{4}$ is crucial to correctly parame- terise a source of stratospheric $\mathrm{H}_{2} \mathrm{O}$, as the main source of stratospheric $\mathrm{H}_{2} \mathrm{O}$ is the oxidation of methane (e.g. Bates and Nicolet, 1950; Jones and Pyle, 1984; Le Texier et al., 1988).

The new scheme we develop for the present study has the advantage of providing a consistent stratospheric parameterisation of both $\mathrm{CH}_{4}$ and $\mathrm{H}_{2} \mathrm{O}$. In this way our new scheme provides not only stratospheric $\mathrm{H}_{2} \mathrm{O}$ increments but also a realistic $\mathrm{CH}_{4}$ tracer for the global GCM. In this study we show that this $\mathrm{CH}_{4}$ tracer can also act as a suitable transport tracer for online stratospheric circulation assessments, which has enabled coherent comparisons of stratospheric transport in the GCM and the offline chemistry-transport model (CTM). Our study also evaluates the effect that improving the description of the stratospheric composition has on temperature and radiative effects. The new scheme, called CoMeCAT (Coefficients for Methane from a Chemistry And Transport model), can be implemented within any global model, and has been tested here within the TOMCAT/SLIMCAT CTM (Chipperfield, 2006) and the ECMWF GCM. The way CoMeCAT is formulated (see Sect. 2.2) allows for the simulation of changes in stratospheric $\mathrm{H}_{2} \mathrm{O}$ due to both forcings (via $\mathrm{CH}_{4}$ oxidation) and feedbacks (via changes in TTL temperatures).

This paper is organised as follows. Section 2 discusses the existing parameterisations for stratospheric $\mathrm{H}_{2} \mathrm{O}$ and presents the new linear approach we adopt to parameterise $\mathrm{CH}_{4}$ and $\mathrm{H}_{2} \mathrm{O}$ in the stratosphere. The calculation of the linear coefficients for the scheme is explained in Sect. 3, where the observations used for validation are also introduced, and the performance of the $\mathrm{CH}_{4}$ parameterisation in the two different global models is assessed. Section 4 discusses the ability of the scheme to model stratospheric $\mathrm{H}_{2} \mathrm{O}$. Results of stratospheric transport from nudged GCM simulations are evaluated in Sect. 5. The impacts of $\mathrm{CH}_{4}$ on stratospheric temperatures and radiative forcing calculations are discussed in Sect. 6. Our conclusions and an outline of future research are in Sect. 7.

\section{Parameterisations for stratospheric $\mathrm{H}_{2} \mathrm{O}$}

\subsection{Existing schemes}

A few approaches exist for the parameterisation of water vapour in the stratosphere (Dethof, 2003; MacKenzie and Harwood, 2004; Austin et al., 2007; McCormack et al., 2008), but there are important issues that remain unsolved: the lack of a realistic latitudinal variability (Dethof, 2003), and the lack of an interactive link between $\mathrm{CH}_{4}$ and $\mathrm{H}_{2} \mathrm{O}$ (McCormack et al., 2008). Also, most of the models used to obtain these parameterisations are two dimensional, therefore missing the influence of longitudinal features. The exception is the scheme proposed by Austin et al. (2007), which, as discussed below in more detail, overcomes these problems but requires tracers (e.g. an age-of-air tracer) that 
are not usually available in NWP models and data assimilation systems (DAS).

In a global model the total hydrogen amount $\mathcal{H}$,

$\mathcal{H}=\mathrm{H}_{2} \mathrm{O}+2 \cdot \mathrm{CH}_{4}+\mathrm{H}_{2} \mathrm{CO}+\mathrm{H}_{2}$,

must be conserved under mixing and transport. Recent studies have shown that the quantity $\mathcal{H}$ is also uniformly distributed in the stratosphere when the last two terms are neglected (e.g. Randel et al., 2004; Austin et al., 2007).

The current ECMWF model includes a simple parameterisation of stratospheric water vapour based on the oxidation of $\mathrm{CH}_{4}$ (Dethof, 2003). The basis of such scheme is the observation that the following quantity is fairly uniformly distributed in the stratosphere with a value of $\sim 6.8 \mathrm{ppmv}^{1}$ (Randel et al., 2004):

$\tilde{\mathcal{H}}=2\left[\mathrm{CH}_{4}\right]+\left[\mathrm{H}_{2} \mathrm{O}\right] \sim 6.8 \mathrm{ppmv}$,

where [ ] stands for volume mixing ratio (vmr).

The ECMWF model assumes, therefore, that the vmr of water vapour $\left[\mathrm{H}_{2} \mathrm{O}\right]$ in the stratosphere increases at a rate

$\Delta\left[\mathrm{H}_{2} \mathrm{O}\right]=2 k_{1}\left[\mathrm{CH}_{4}\right]$

or by using Eq. (2),

$\Delta\left[\mathrm{H}_{2} \mathrm{O}\right]=k_{1}\left(6.8-\left[\mathrm{H}_{2} \mathrm{O}\right]\right)$,

which is expressed in ppmv and can also be written in terms of specific humidity, $q$, by simply dividing by $1.6 \times 10^{6}$ as

$\Delta q=k_{1}(Q-q)$,

where $Q=4.25 \times 10^{-6}\left(\mathrm{~kg} \mathrm{~kg}^{-1}\right)$. In addition, above approximately $60 \mathrm{~km}$ a term for the $\mathrm{H}_{2} \mathrm{O}$ loss by photolysis is added, and so the complete humidity parameterisation in the ECMWF model is

$\Delta q=k_{1}(Q-q)-k_{2} q$.

The rate $k_{1}$ can be determined from a model with detailed $\mathrm{CH}_{4}$ chemistry, such as was done in the past with the 2D model of the University of Edinburgh (R. S. Harwood, personal communication, 2005). Nevertheless, a simpler option is used at present by ECMWF, where analytical forms for $k_{1}$ and $k_{2}$ as a function of pressure are used so that the photochemical lifetime of water vapour follows that shown in Brasseur and Solomon (2005). There is no latitudinal or seasonal dependency included in the ECMWF scheme, nor any variation in the $\mathrm{CH}_{4}$ oxidation source (due for instance to increasing tropospheric concentrations of this gas). The ECMWF model does not assimilate stratospheric humidity data operationally, but uses the background humidity field directly in the analysis. Therefore, it is the model dynamics and physics that shapes the stratospheric humidity, ultimately constrained to observations by the wind and temperature fields (Simmons et al., 1999).

\footnotetext{
1 parts per million by volume
}

MacKenzie and Harwood (2004) used the Thin Air 2D photochemical model (Kinnersley and Harwood, 1993) to obtain the rate coefficient $k$ for the pseudo-reaction that groups the whole $\mathrm{CH}_{4}$ oxidation process described by Le Texier et al. (1988), $\mathrm{CH}_{4} \stackrel{k}{\rightarrow} 2 \mathrm{H}_{2} \mathrm{O}$; $k$ was obtained as a function of latitude, altitude and season. Austin et al. (2007) studied the evolution of stratospheric $\mathrm{H}_{2} \mathrm{O}$ concentrations in a chemistry climate model (CCM) ensemble run from 1960 to 2005. They examined the $\mathrm{H}_{2} \mathrm{O}$ concentrations coming from the $\mathrm{CCM}$ photochemistry scheme (via $\mathrm{CH}_{4}$ oxidation), and concentrations obtained from a parameterisation involving entry rates, $\mathrm{CH}_{4}$ oxidation and also mean age-of-air, as the amount of $\mathrm{CH}_{4}$ oxidised depends on the time air masses have spent in the stratosphere. They formulated the water concentration at a stratospheric location $\boldsymbol{x}$ and time $t$ to be

$\mathrm{H}_{2} \mathrm{O}(\boldsymbol{x}, t)=A+B$.

The entry term, $A$, and the methane oxidation term, $B$, can be expressed as

$A=\left.\mathrm{H}_{2} \mathrm{O}\right|_{e}(t-\gamma)$,

$B=2 \cdot\left[\left.\mathrm{CH}_{4}\right|_{0}(t-\gamma)-\mathrm{CH}_{4}(\boldsymbol{x}, t)\right]$,

where $\gamma=\gamma(\boldsymbol{x}, t)$ is the mean age-of-air for that particular location, and $\left.\mathrm{H}_{2} \mathrm{O}\right|_{e}$ is the water vapour concentration for that particular air parcel at stratospheric entry. At present, the kind of parameterisation used in Austin et al. (2007) cannot be implemented by ECMWF due to the lack of age-ofair and $\mathrm{CH}_{4}$ tracers in their IFS model. McCormack et al. (2008) described a parameterisation for water vapour production and loss to be used in a high-altitude NWP/DAS system. Their method is similar to the current approach in the ECMWF model, with the improvement of including latitudinal variation. However, they did not include $\mathrm{C}_{4}$ tracer, focusing on the parameterisation of $\mathrm{H}_{2} \mathrm{O}$ directly, and, in a similar way to MacKenzie and Harwood (2004), they obtain the coefficients $k_{1}$ and $k_{2}$ in Eq. (6) with a 2-D photochemical model as function of altitude, latitude and season. The main advantage of the scheme in McCormack et al. (2008) is its high altitude range. Nevertheless, their study was mainly concerned with the mesospheric region $(10-0.001 \mathrm{hPa})$, and provides no comparative results for our stratospheric study.

Our scheme differs from that in McCormack et al. (2008) in the conceptual approach of the parameterisation, as ours focuses on parameterising $\mathrm{CH}_{4}$ in the stratosphere and then using it to obtain a source of stratospheric water vapour. Unlike McCormack et al. (2008) and MacKenzie and Harwood (2004), in which a 2-D model was used, we use a 3-D CTM to obtain the new $\mathrm{CH}_{4}$ and $\mathrm{H}_{2} \mathrm{O}$ scheme. 


\subsection{New linear approach for $\mathrm{CH}_{4}$ and $\mathrm{H}_{2} \mathrm{O}$}

In the stratosphere $\mathrm{CH}_{4}$ is only destroyed by oxidation; therefore, the time tendency of stratospheric $\mathrm{CH}_{4}$ due to chemistry corresponds to

$\frac{\partial\left[\mathrm{CH}_{4}\right]}{\partial t}=-L\left[\mathrm{CH}_{4}\right]$,

where [ ] indicates concentrations and $L$ is the $\mathrm{CH}_{4}$ loss rate $\left(\mathrm{s}^{-1}\right)$.

Loss of $\mathrm{CH}_{4}$ in the stratosphere takes place mainly through the following reactions:

$\mathrm{CH}_{4}+\mathrm{OH} \rightarrow \mathrm{CH}_{3}+\mathrm{H}_{2} \mathrm{O}$,

$\mathrm{CH}_{4}+\mathrm{O}\left({ }^{1} \mathrm{D}\right) \rightarrow \mathrm{CH}_{3}+\mathrm{OH}$,

$\mathrm{CH}_{4}+\mathrm{Cl} \rightarrow \mathrm{CH}_{3}+\mathrm{HCl}$.

Based on such reactions, the oxidation rate of $\mathrm{CH}_{4}$ can be written as

$L=k_{1}[\mathrm{OH}]+k_{2}\left[\mathrm{O}\left({ }^{1} \mathrm{D}\right)\right]+k_{3}[\mathrm{Cl}]$,

where the rate constants $k_{i}(i=1,2,3)$ are given in $\left(\mathrm{cm}^{3}\right.$ molecule $\mathrm{e}^{-1} \mathrm{~s}^{-1}$ ).

Full-chemistry 3-D models such as SLIMCAT calculate the oxidation rate in Eq. (11) analytically from the explicit reactions. However, in order to provide NWP models with a simplified methane scheme, an alternative approach has been explored here. $\mathrm{As} \mathrm{CH}_{4}$ is only destroyed, our new scheme parameterises the loss rate $L$. Since the three reactions involved in $\mathrm{CH}_{4}$ destruction depend on temperature (T) and $\left[\mathrm{CH}_{4}\right], L$ can be parameterised following a scheme similar to the one proposed for the ozone tendency by Cariolle and Déqué (Cariolle and Déqué, 1986; Cariolle and Teyssèdre, 2007):

$L\left(\mathrm{CH}_{4}, T\right)=c_{0}+c_{1}\left(\left[\mathrm{CH}_{4}\right]-\overline{\left[\mathrm{CH}_{4}\right]}\right)+c_{2}(T-\bar{T})$.

In this case the coefficients $c_{i}$ are

$c_{0}=L_{0}$,

$c_{1}=\left.\frac{\partial L}{\partial\left[\mathrm{CH}_{4}\right]}\right|_{0}$,

$c_{2}=\left.\frac{\partial L}{\partial T}\right|_{0}$.

$L_{0}$ is the loss rate (subscript 0 indicates values obtained at a reference state), $c_{1}$ represents how the loss rate adjusts with changes in the $\mathrm{CH}_{4}$ concentration, while $c_{2}$ relates to how $L$ varies with temperature. The terms $\overline{\left[\mathrm{CH}_{4}\right]}$ and $\bar{T}$ in Eq. (12) also come from a reference state or climatology.

Since $\mathrm{CH}_{4}$ has no stratospheric source except entry through the tropopause, the CoMeCAT $\mathrm{CH}_{4}$ scheme presented above can also be used to obtain $\mathrm{H}_{2} \mathrm{O}$ tendencies in the stratosphere. Based on an approximation of Eq. (1) where the last two terms have been neglected, the time tendency for water vapour in the stratosphere can be written as

$\frac{\partial\left[\mathrm{H}_{2} \mathrm{O}\right]}{\partial t}=-2 \frac{\partial\left[\mathrm{CH}_{4}\right]}{\partial t}$.
We have implemented such a scheme in TOMCAT/SLIMCAT and ECMWF GCM runs. $\mathrm{CH}_{4}$ has been parameterised following the CoMeCAT approach, and results have been compared to $\mathrm{H}_{2} \mathrm{O}$ observations (see Sect. 4).

\section{The CoMeCAT parameterisation scheme}

\subsection{Coefficients calculation}

CoMeCAT coefficients have been calculated from fullchemistry runs of the global 3-D TOMCAT/SLIMCAT CTM, similar to the method employed in Monge-Sanz et al. (2011) for the calculation of coefficients for a stratospheric ozone scheme. To calculate the coefficients, a TOMCAT box model version was used. The box model configuration is identical to the 3-D CTM (chemical descriptions, grid resolution etc.) except that it does not consider transport processes. The box model was initialised with the zonally averaged output of a full-chemistry simulation of the SLIMCAT 3-D model (run 323). Run 323 is a multiannual SLIMCAT run that uses a $7.5^{\circ} \times 7.5^{\circ}$ horizontal resolution and 24 vertical levels (L24). The run is driven by ERA-40 winds (Uppala et al., 2005) from 1977 to 2001 and by ECMWF operational winds from 2002 to 2006 . The period chosen to initialise the box model is January to December 2004. The box model is initialised by reading input from run 323 for every month of the year 2004, and then a series of 2-day runs is performed for each month. From the initial state, five 2-day runs of the box model were carried out: one control run and four perturbation runs from the initial conditions. In these runs the chemistry was computed every 20 minutes. The resolution adopted for the box model is 24 latitudes, and 24 levels (from the surface up to $\sim 60 \mathrm{~km}$ ), matching the resolution of the full-chemistry run used for the initialisation. The box model also uses the same chemistry module as the full SLIMCAT model.

The reference loss rate $L_{0}$ (coefficient $c_{0}$ ) is obtained from a control run in which the zonal 3-D output is used without alteration to initialise the box model. The loss rate is calculated from the three chemical reactions in Eq. (10). The reference state values of $\overline{\left[\mathrm{CH}_{4}\right]}$ and $\bar{T}$ are directly provided by the zonal output of the SLIMCAT initial state on the 15th of each month, corresponding therefore to year 2004. Then, perturbed runs of the box model are carried out to obtain the coefficients $c_{1}$ and $c_{2}$. To obtain $c_{1}$, variations in $\left[\mathrm{CH}_{4}\right]$ of $\pm 5 \%$ with respect to the reference state are introduced, and variations of $\pm 4.0 \mathrm{~K}$ to obtain $c_{2}$. The calculation results in a set of coefficients for each latitude, level and month of the year. The coefficients and climatologies are provided as five look-up tables $\left(c_{0}, c_{1}, c_{2}, \overline{\left[\mathrm{CH}_{4}\right]}\right.$ and $\left.\bar{T}\right)$ for every month. These CoMeCAT coefficients are available for research purposes upon request. 
Table 1. TOMCAT/SLIMCAT CTM runs performed with the CoMeCAT scheme and full-chemistry run323. For each run, the CTM mode $(\sigma-\theta$ SLIMCAT or $\sigma-p$ TOMCAT) and the winds used to drive the simulation are indicated. For the runs using the CoMeCAT scheme, the terms of the parameterisation that have been active for the particular run are also included. Winds for the runs with CoMeCAT correspond to year 2000 .

\begin{tabular}{ccccc}
\hline CTM run & CTM mode & Winds & $\mathrm{CH}_{4}$ & Active terms \\
\hline run13 & SLIMCAT & ERA-40 & CoMeCAT & $\mathrm{c}_{0}, \mathrm{c}_{1}, \mathrm{c}_{2}$ \\
run130 & SLIMCAT & ERA-40 & CoMeCAT & $\mathrm{c}_{0}$ \\
run131 & SLIMCAT & ERA-40 & CoMeCAT & $\mathrm{c}_{0}, \mathrm{c}_{1}$ \\
run14 & TOMCAT & ERA-40 & CoMeCAT & $\mathrm{c}_{0}, \mathrm{c}_{1}, \mathrm{c}_{2}$ \\
run15 & TOMCAT & ERA-Interim & CoMeCAT & $\mathrm{c}_{0}, \mathrm{c}_{1}, \mathrm{c}_{2}$ \\
run323 & SLIMCAT & ERA-40 & full-chem & - \\
\hline
\end{tabular}

a) JANUARY $\mathrm{CH} 4$ (ppmv)

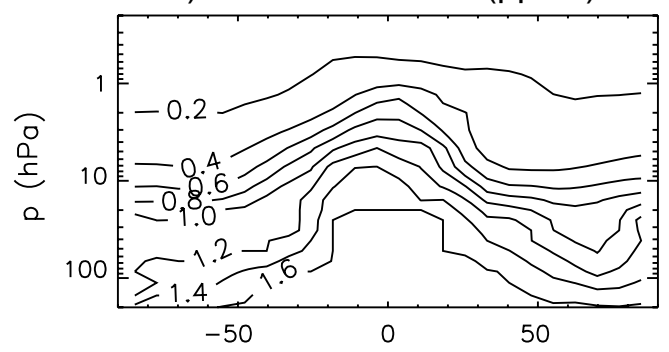

c) JULY CH4 (ppmv)

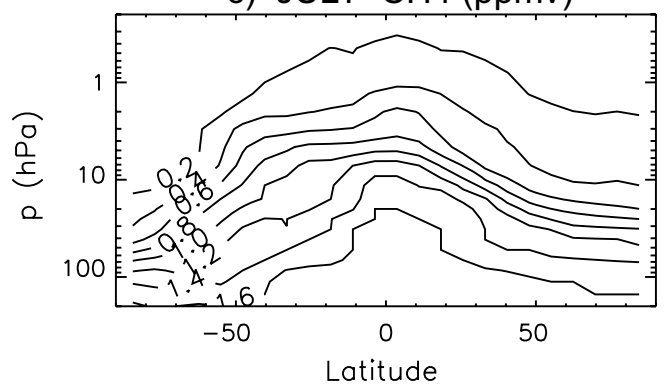

b) JANUARY T(K)

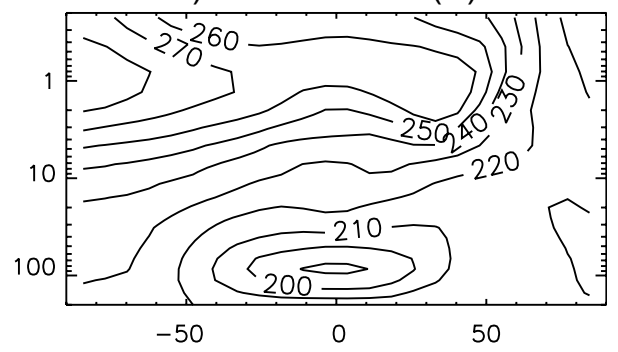

d) JULY $T(K)$

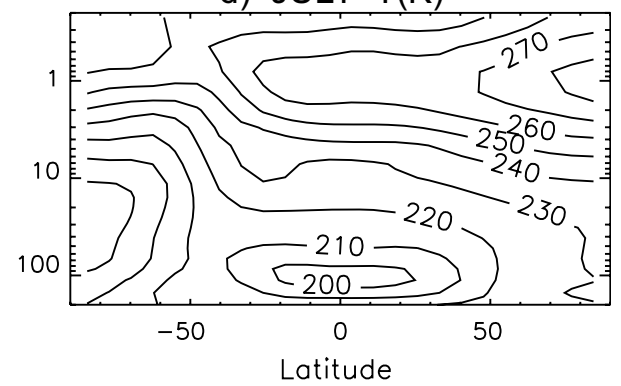

Fig. 1. Zonal mean of CoMeCAT $\overline{\left[\mathrm{CH}_{4}\right]}$ (ppmv) (left panels) and temperature $\bar{T}$ (K) (right panels) reference terms for January (top row) and July (bottom row) 2004. These reference terms come from the SLIMCAT CTM (see main text for details, Sect. 3.1).

Figure 1 plots the zonal mean of the reference values for $\overline{\left[\mathrm{CH}_{4}\right]}$ and $\bar{T}$ for January and July. Stratospheric $\mathrm{CH}_{4}$ in the full-chemistry SLIMCAT has been widely validated, and compares very well with MIPAS observations (e.g. Kouker, 2005). The temperature field corresponds to ECMWF operational data for 2004 interpolated onto the CTM grid. The CoMeCAT zonal mean $\mathrm{CH}_{4}$ lifetime, $\tau$, is plotted in Fig. 2 for January, April, July and October. The minimum lifetime values are reached at $\sim 1 \mathrm{hPa}$, and are almost $1 \mathrm{yr}$ over the summer pole, where the maximum $\mathrm{CH}_{4}$ loss rate occurs. Above $1 \mathrm{hPa}, \mathrm{CH}_{4}$ loss decreases (lifetime increases) due to the decrease in the abundance of $\mathrm{OH}$. The lifetime values in Fig. 2 are in overall agreement with those in Brasseur and Solomon (2005).
The methane time tendency is controlled mainly by the first coefficient $c_{0}$, and the other terms add corrections due to changes in $\mathrm{CH}_{4}$ and temperature. Figure 3 shows the impact that changes in $\mathrm{CH}_{4}$ concentrations have on the loss rate (coefficient $c_{1}$ ) for the months of January, April, July and October. Similarly, Fig. 4 shows how temperature changes feed back on the loss rate. Note that the minus sign in Eq. (9) has been included when calculating the coefficients $c_{i}$, so the scheme actually parameterises $L^{\prime}=-L$. In the middle stratosphere, an increase in $\mathrm{CH}_{4}$ concentration causes a decrease in loss rate $L$ (Fig. 3), explained by the fact that a $\mathrm{CH}_{4}$ increase implies a decrease of $\mathrm{ClO}$ at around $40 \mathrm{~km}$ and an overall decrease of $\mathrm{HO}_{\mathrm{x}}$, which leads to a decrease in $\mathrm{CH}_{4}$ loss. The opposite effect occurs in the lower stratosphere (LS) region and above the stratopause, where a $\mathrm{CH}_{4}$ increase causes an increased loss rate. 
a) JANUARY

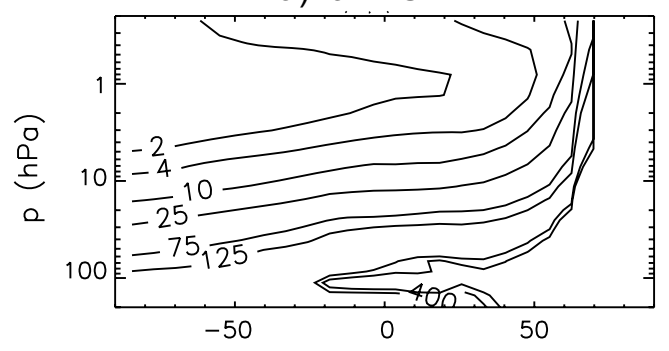

c) JULY

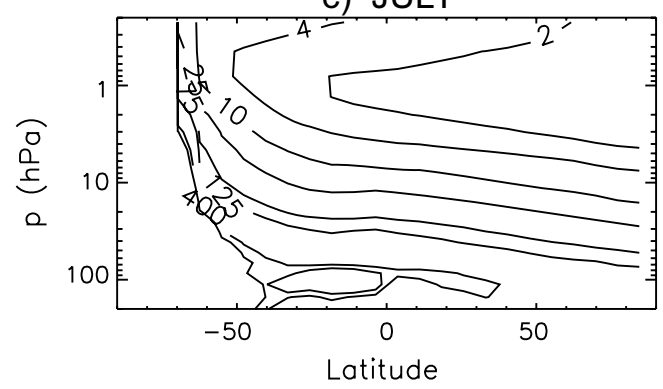

b) APRIL

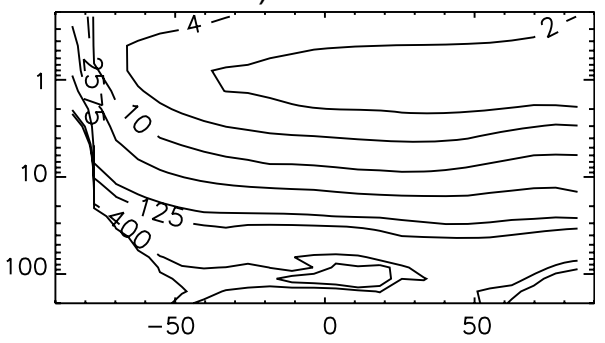

d) OCTOBER

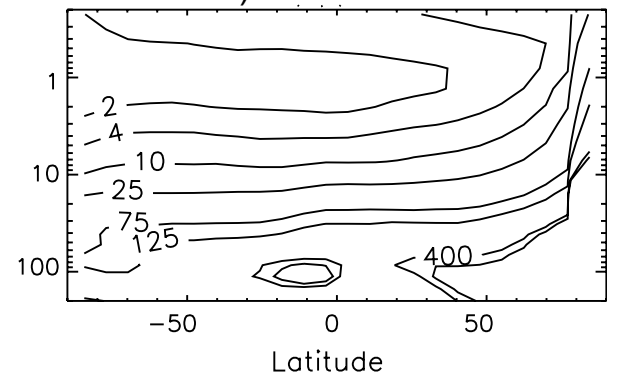

Fig. 2. Altitude-latitude distribution of CoMeCAT $\mathrm{CH}_{4}$ lifetime $\tau$ (inverse of the loss rate). Values of $\tau$ are shown, in years, for (a) January, (b) April, (c) July and (d) October.

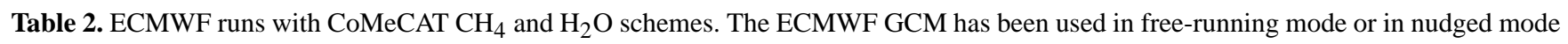
to reanalyses as shown. In all these runs stratospheric $\mathrm{CH}_{4}$ and $\mathrm{H}_{2} \mathrm{O}$ can come from the CoMeCAT scheme, from the default ECMWF option or remain inactive, as indicated. For the runs included here the CoMeCAT scheme was not interactive with the ECMWF radiation scheme. The meteorology used for the nudged runs corresponds to year 2000.

\begin{tabular}{cccc}
\hline ECMWF run & GCM & $\mathrm{CH}_{4}$ scheme & $\mathrm{H}_{2} \mathrm{O}$ scheme \\
\hline fif4 & Free GCM & CoMeCAT & ECMWF default \\
fi6n & Free GCM & CoMeCAT & CoMeCAT \\
fif5 & Free GCM & none & none \\
fh22 & Nudged to ERA-40 every $6 \mathrm{~h}$ & CoMeCAT & ECMWF default \\
fh23 & Nudged to ERA-Interim every $6 \mathrm{~h}$ & CoMeCAT & ECMWF default \\
\hline
\end{tabular}

The values of $c_{2}$ (loss tendency with respect to temperature) are negative everywhere except in the equatorial LS (between 100 and $200 \mathrm{hPa}$ ) and in the Arctic summer LS (Fig. 4). The negative sign agrees with the fact that by increasing temperature, $k_{i}$ in Eq. (11) increases, which means more $\mathrm{CH}_{4}$ loss. The decrease in loss over the Arctic summer (positive contours in Fig. 4c) is explained by a secondary effect, coming from decreased $\mathrm{OH}$ concentrations at higher temperature, that outweighs the direct temperature effect in this region.

\subsection{HALOE observations of $\mathrm{CH}_{4}$ and $\mathrm{H}_{2} \mathrm{O}$}

The results of the model simulations in this study have been validated against observations from the Halogen Occultation Experiment (HALOE) instrument, on board the Upper Atmosphere Research Satellite (UARS, Russell et al., 1993) of $\mathrm{CH}_{4}$ (Park et al., 1996) and $\mathrm{H}_{2} \mathrm{O}$ (Harries et al., 1996). The
HALOE data used in our study correspond to the third public release v19 (W. Randel and F. Wu, personal communication, 2006). These HALOE data are zonally averaged and are available for 41 latitudes $\left(80^{\circ} \mathrm{N}-80^{\circ} \mathrm{S}\right)$ and 49 pressure levels (from 100 to $0.01 \mathrm{hPa}$ ); the monthly time series covers the period November 1991-November 2005. The accuracy for these $\mathrm{CH}_{4}$ observations is better than $7 \%$ between 1 and $100 \mathrm{hPa}$ (Park et al., 1996) and $10 \%$ for $\mathrm{H}_{2} \mathrm{O}$ measurements at the same altitude range. Such HALOE data have been widely validated and have been used for several model results validations (e.g. Chipperfield et al., 2002; Bregman et al., 2006; Eyring et al., 2006; Feng et al., 2007).

\subsection{CoMeCAT methane distributions}

Table 1 describes the 3-D CTM runs that have been performed using ERA-40 (Uppala et al., 2005) and ERA-Interim winds (Dee et al., 2011). The SLIMCAT (with hybrid $\sigma$ - 

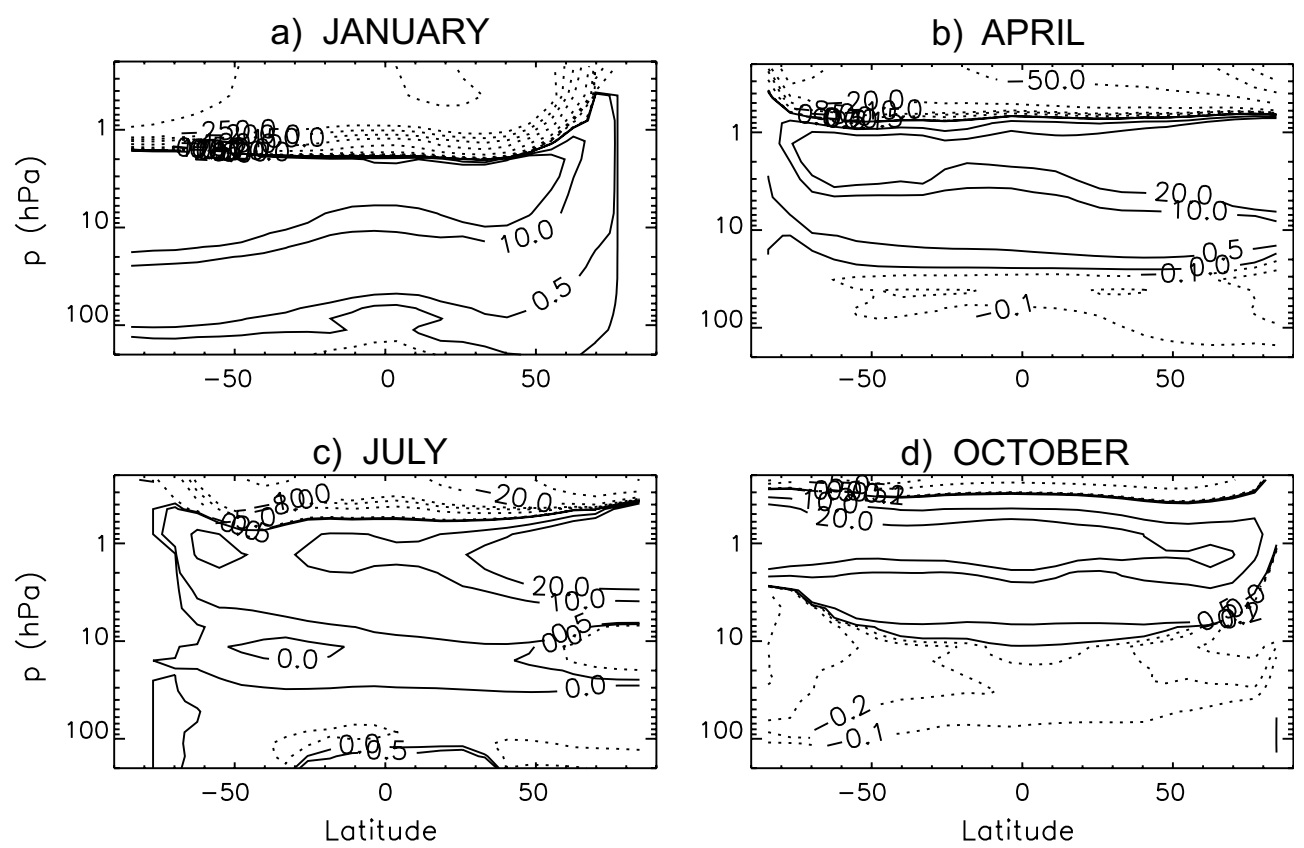

Fig. 3. Altitude-latitude distribution of the CoMeCAT loss tendency with $\left[\mathrm{CH}_{4}\right]$ (coefficient $\left.c_{1}\right)$ in units of $\left(10^{-14} \mathrm{day}^{-1} \mathrm{ppmv}^{-1}\right)$ for $(\mathbf{a})$ January, (b) April, (c) July and (d) October. Solid contours indicate positive values; dashed contours indicate negative values.
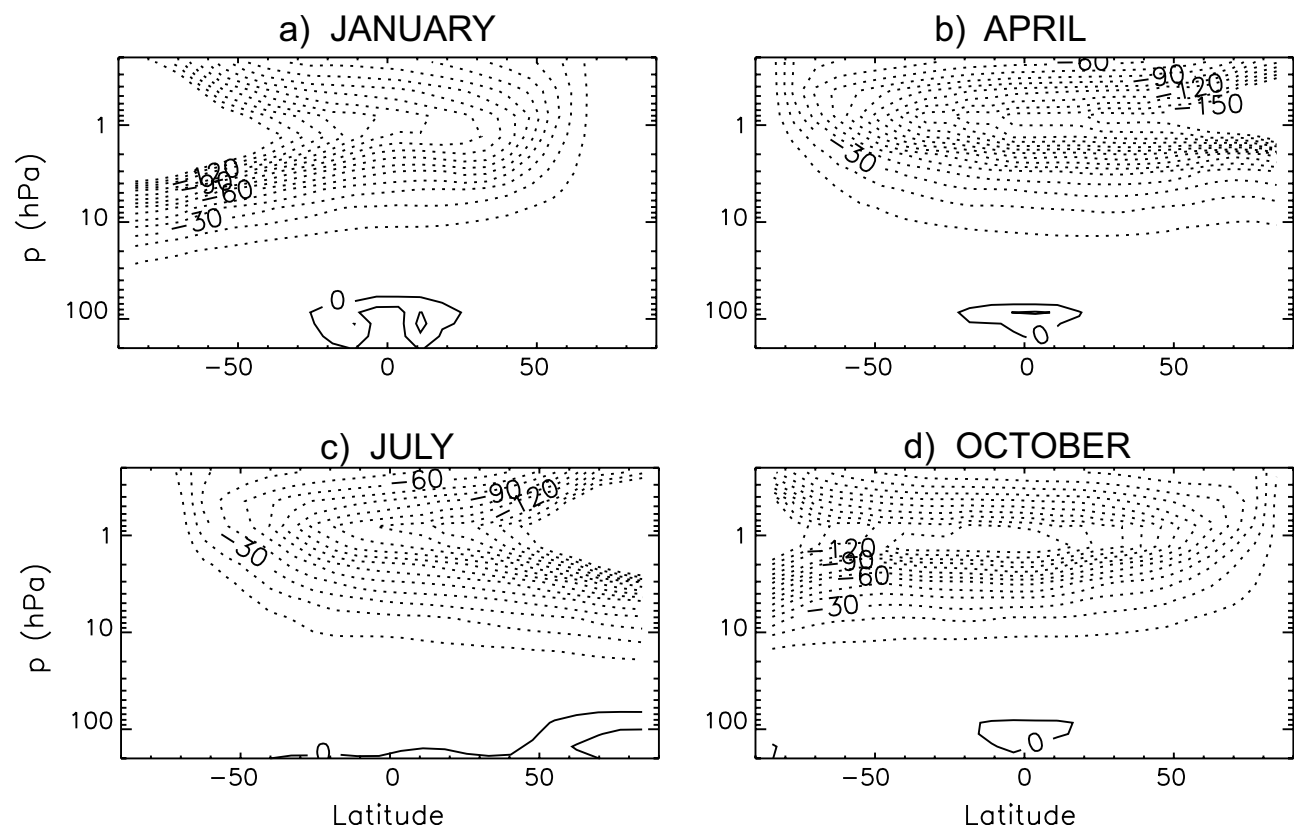

Fig. 4. Altitude-latitude distribution of the CoMeCAT loss tendency with temperature (coefficient $\left.c_{2}\right)$ in units of $\left(10^{-16} d a y^{-1} K^{-1}\right)$ for (a) January, (b) April, (c) July and (d) October. Contours are plotted every 10 units. Solid contours indicate positive values; dashed contours indicate negative values.

$\theta$ vertical levels) runs driven by ERA-40 winds include those using the CoMeCAT scheme for $\mathrm{CH}_{4}$ (run13, run130, run131) and one full chemistry run (run323). There are also two TOMCAT ( $\sigma$-p vertical coordinate) runs which implement the CoMeCAT scheme, one driven by ERA-40 and the other by ERA-Interim winds. The $\mathrm{CH}_{4}$ tracer in these 3-D CTM runs was initialised with the concentrations from the reference climatology $\left[\overline{\mathrm{CH}_{4}}\right]$. The same climatology was used to overwrite the tracer value at the surface at every time step to prevent the surface values from drifting during the 

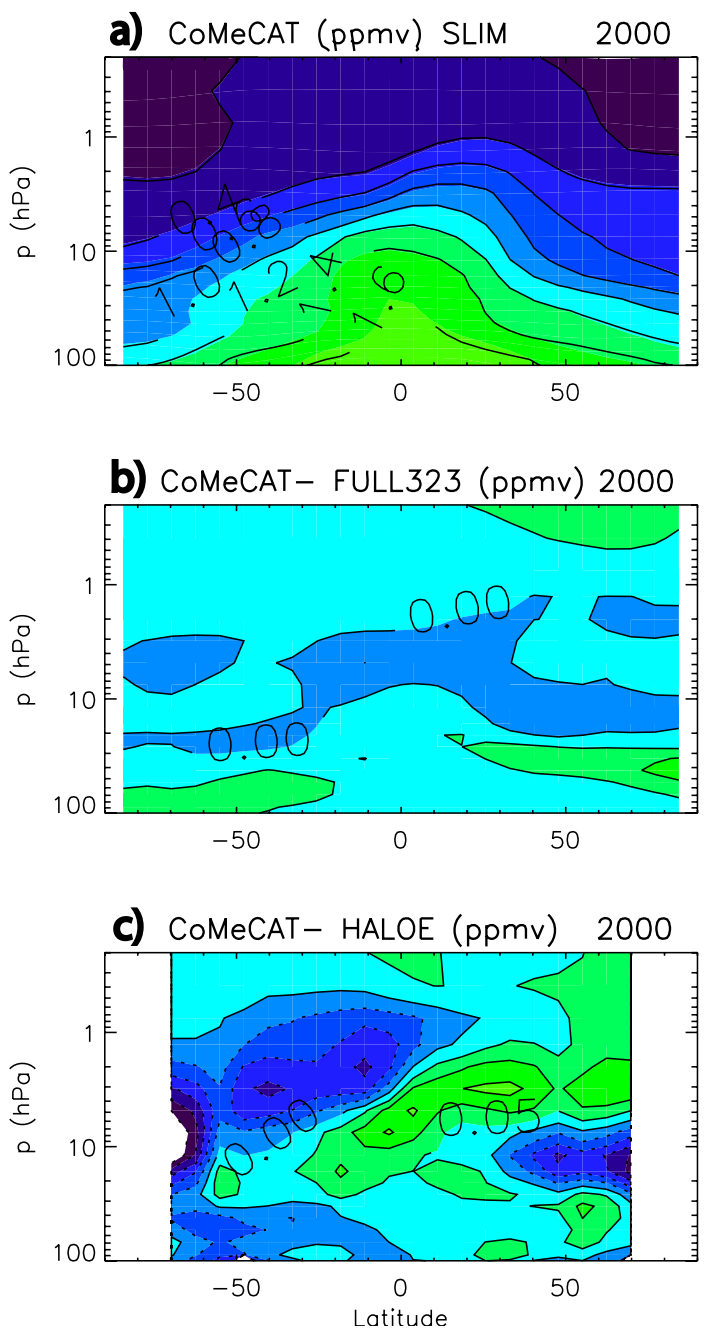

Fig. 5. Annual mean for year 2000 of (a) zonally averaged $\mathrm{CH}_{4}$ distributions (ppmv) from the CoMeCAT scheme in the CTM run13, (b) differences between CoMeCAT and full-chemistry run of SLIMCAT (run323) and (c) differences between CoMeCAT and HALOE observations. The model simulations use ERA-40 winds. Contour values are 0.20 ppmv for (a) and 0.05 ppmv for (b) and (c). Colour scale in (a) goes from larger concentrations (darkest green) to smaller concentrations (darkest blue), while for (b) and (c) the colour scale indicates most positive differences (in darkest green) and most negative differences (in darkest blue). HALOE observations are available for the latitudinal range $80^{\circ} \mathrm{S}-80^{\circ} \mathrm{N}$.

model simulations. A series of runs with the ECMWF GCM (IFS) has also been carried out using the CoMeCAT scheme (Table 2). The runs were performed with the Cy36r1 model version with a T159 horizontal resolution $\left(1.125^{\circ}\right)$ and 60 vertical levels up to $0.1 \mathrm{hPa}$.

\subsubsection{CoMeCAT against full chemistry}

Figure 5 shows the annual mean zonal average $\mathrm{CH}_{4}$ concentrations from the parameterisation in run13, as well as dif- ferences with the full-chemistry run323 and with HALOE $\mathrm{CH}_{4}$ measurements above $100 \mathrm{hPa}$. Results in Fig. 5 correspond to year 2000, which is different to the year used to compute the CoMeCAT coefficients (meteorological conditions of 2004, Sect. 3.1). Both simulations, CoMeCAT and full chemistry used the same ECMWF ERA-40 winds. The CoMeCAT parameterisation is able to capture all general features and variability. There are differences over the tropics above $10 \mathrm{hPa}$, where $\mathrm{CoMeCAT} \mathrm{CH}_{4}$ concentrations are slightly smaller (up to $0.05 \mathrm{ppmv}$ ), as well as in LS high latitudes, where CoMeCAT simulates up to $0.10 \mathrm{ppmv}$ more than SLIMCAT full chemistry over the Arctic. The overall agreement with HALOE is good; modelled concentrations, both CoMeCAT and full chemistry, are up to $0.20 \mathrm{ppmv}$ smaller than HALOE in the most upper levels (above $20 \mathrm{hPa}$ ) in the Southern Hemisphere ( $\mathrm{SH})$, with maximum differences concentrated around $10 \mathrm{hPa}$ at high latitudes in both hemispheres. CoMeCAT simulates more $\mathrm{CH}_{4}$ than observed over the tropical mid-stratosphere and most upper levels at high Northern Hemisphere (NH) latitudes. The differences between the two modelled $\mathrm{CH}_{4}$ fields (CoMeCAT and full chemistry) are smaller than the differences between the modelled fields and HALOE observations.

Annually averaged (year 2000) vertical $\mathrm{CH}_{4}$ distributions from CoMeCAT and from the full-chemistry run 323 between 100 and $0.2 \mathrm{hPa}$ are shown in Fig. 6 for five different latitudes. The CoMeCAT vertical distribution in the SLIMCAT run (run13) agrees well with the full-chemistry run. The most significant differences occur above $1 \mathrm{hPa}$, where CoMeCAT overestimates $\mathrm{CH}_{4}$ by up to $0.1 \mathrm{ppmv}$, and below $30 \mathrm{hPa}$, where the parameterisation, especially at southern mid-latitudes, results in smaller concentrations than the full chemistry (up to 0.05 ppmv smaller). CoMeCAT in the TOMCAT run (run14) is also in good agreement with full chemistry in the LS, but in the middle and upper stratosphere it simulates more $\mathrm{CH}_{4}$ than the SLIMCAT run13. Above $1 \mathrm{hPa}$ differences of up to $0.25 \mathrm{ppmv}$ occur widely and run 14 results in up to 0.40 ppmv more than run323 in the highest levels at tropical latitudes, the reason for these differences is the too fast vertical transport in the TOMCAT run (MongeSanz et al., 2007).

Two additional CTM runs have been performed to determine the contribution of the individual terms in the parameterisation. These two runs are analogous to run13 (Table 1), but for one of them (run130) only the first term of the parameterisation ( $\mathrm{c}_{0}$ in Eq. 12) is used, and for the second run (run131) only the first two terms in Eq. (12) are used. Figure 7 shows the annually averaged profiles of the differences between the three runs (run13, run130 and run131) for five different latitudes. As discussed in Sect. 3.1, the main contribution is made by the first term of the parameterisation, $c_{0}$. The next two terms add corrections of up to $\sim 10 \%$ of the total concentration. It is in the middle stratosphere where $c_{1}$ and $c_{2}$ make their main absolute contributions. The $c_{1}$ term (i.e. indirect $\mathrm{CH}_{4}$ effect) contributes most over mid- and high 

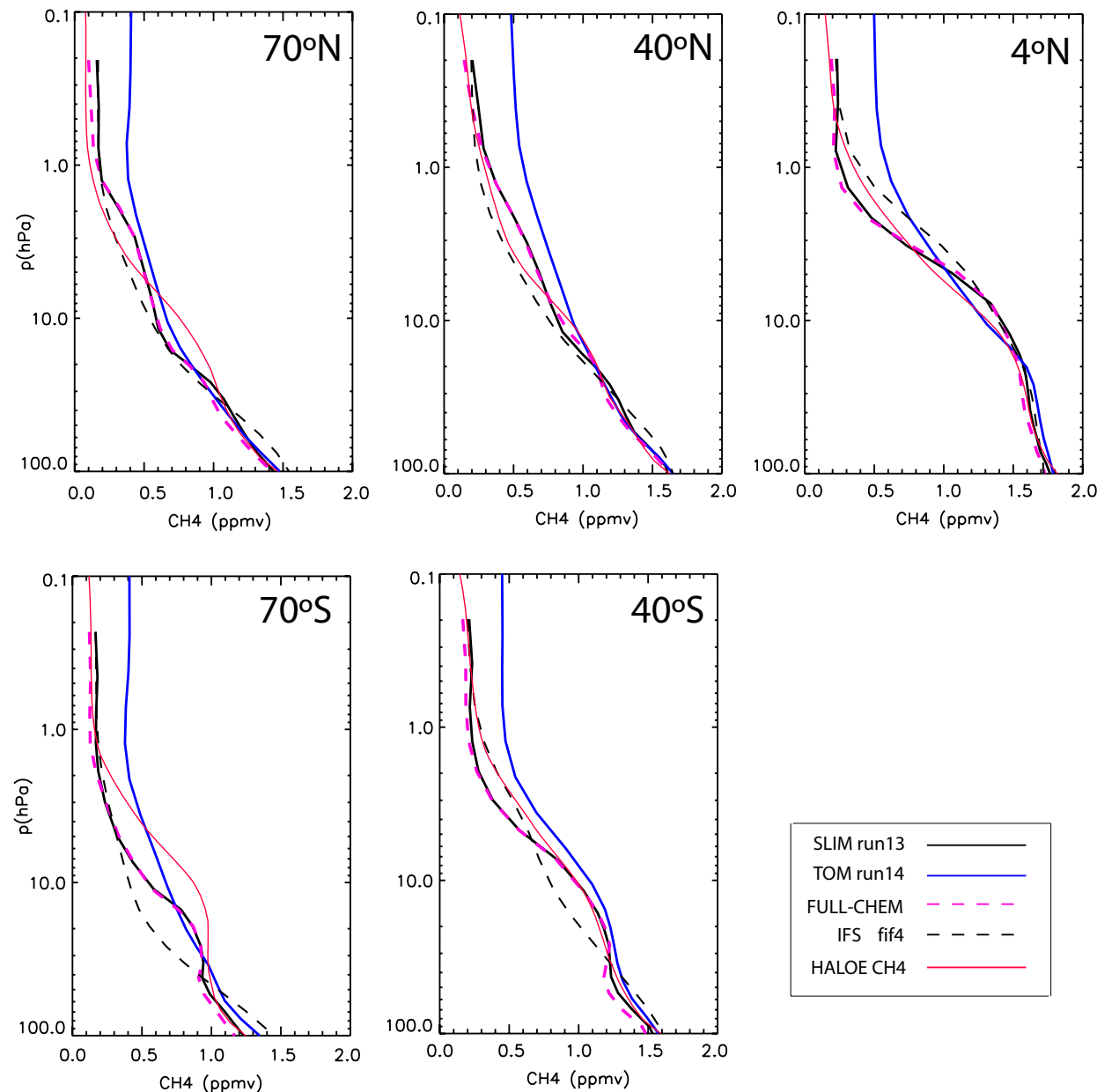

Fig. 6. Annually averaged $\mathrm{CH}_{4}$ distributions (ppmv) for year 2000 from the CoMeCAT scheme in SLIMCAT run13 (solid black line), TOMCAT run 14 (blue line) and in the ECMWF GCM (dashed black line) run fif4 (Table 2) for the latitudes $70^{\circ} \mathrm{N}, 40^{\circ} \mathrm{N}, 4^{\circ} \mathrm{N}, 70^{\circ} \mathrm{S}$ and $40^{\circ} \mathrm{S}$ (as labelled). HALOE observations have also been included (red line), as well as the CTM full-chemistry run323 (red dashed line).

latitudes above $20 \mathrm{hPa}$. The $c_{2}$ term (i.e. the indirect $\mathrm{T}$ effect) in run 13 reduces the $\mathrm{CH}_{4}$ values between 30 and $3 \mathrm{hPa}$ with respect to run131 (Fig. 7). In the uppermost levels (above $2 \mathrm{hPa}$ ), the $c_{2}$ term acts to increase the concentrations, especially over mid- and low latitudes.

\subsubsection{CoMeCAT in the GCM}

The ECMWF runs were initialised with the $\mathrm{CH}_{4}$ reference field from the CTM. Figure 6 shows annually averaged $\mathrm{CH}_{4}$ vertical distributions from the CoMeCAT scheme in the CTM and in the ECMWF GCM (run fif4). Two different CTM runs are included: the default SLIMCAT $(\sigma-\theta)$ one (run13) and also one TOMCAT $(\sigma-p)$ run (run14) for a better comparison against the ECMWF runs, which, like the GCM, also uses a $\sigma-p$ vertical coordinate. The overall agreement in the LS (up to $10 \mathrm{hPa}$ ) is good between all runs and observations (with differences smaller than $0.1 \mathrm{ppmv}$ ); larger differences occur above $10 \mathrm{hPa}$. At the highest levels the agreement with observations is good for fif 4 and SLIMCAT run13, also within 0.1 ppmv difference. Between 1 and $10 \mathrm{hPa}$ the ECMWF CoMeCAT run (fif4) simulates smaller concentrations than the full chemistry (by up to $0.2 \mathrm{ppmv}$ ) at high and mid-latitudes in the $\mathrm{NH}$; while in the $\mathrm{SH}$ the underestimation (up to $0.3 \mathrm{ppmv}$ ) takes place between 5 and $50 \mathrm{hPa}$. Over the tropics the ECMWF run is very close to the SLIMCAT runs in the LS and middle stratosphere. This, together with the fact that in the upper levels fif4 is more realistic than TOMCAT forced by ERA-40 winds, shows the improvement in the vertical transport achieved in the recent ECMWF model versions (e.g. Monge-Sanz et al., 2007, 2012). Nevertheless, definitive conclusions cannot be drawn on this issue since the vertical motion used in the model runs is different: The CTM obtains it from the divergence of the horizontal winds, while the ECMWF runs use the instantaneous vertical wind velocity $w$. The ECMWF $w$ field had been reported to be too noisy in the past (e.g. Fueglistaler et al., 2004; Krüger et al., 2008; Tegtmeier et al., 2008), while more recent studies point to 

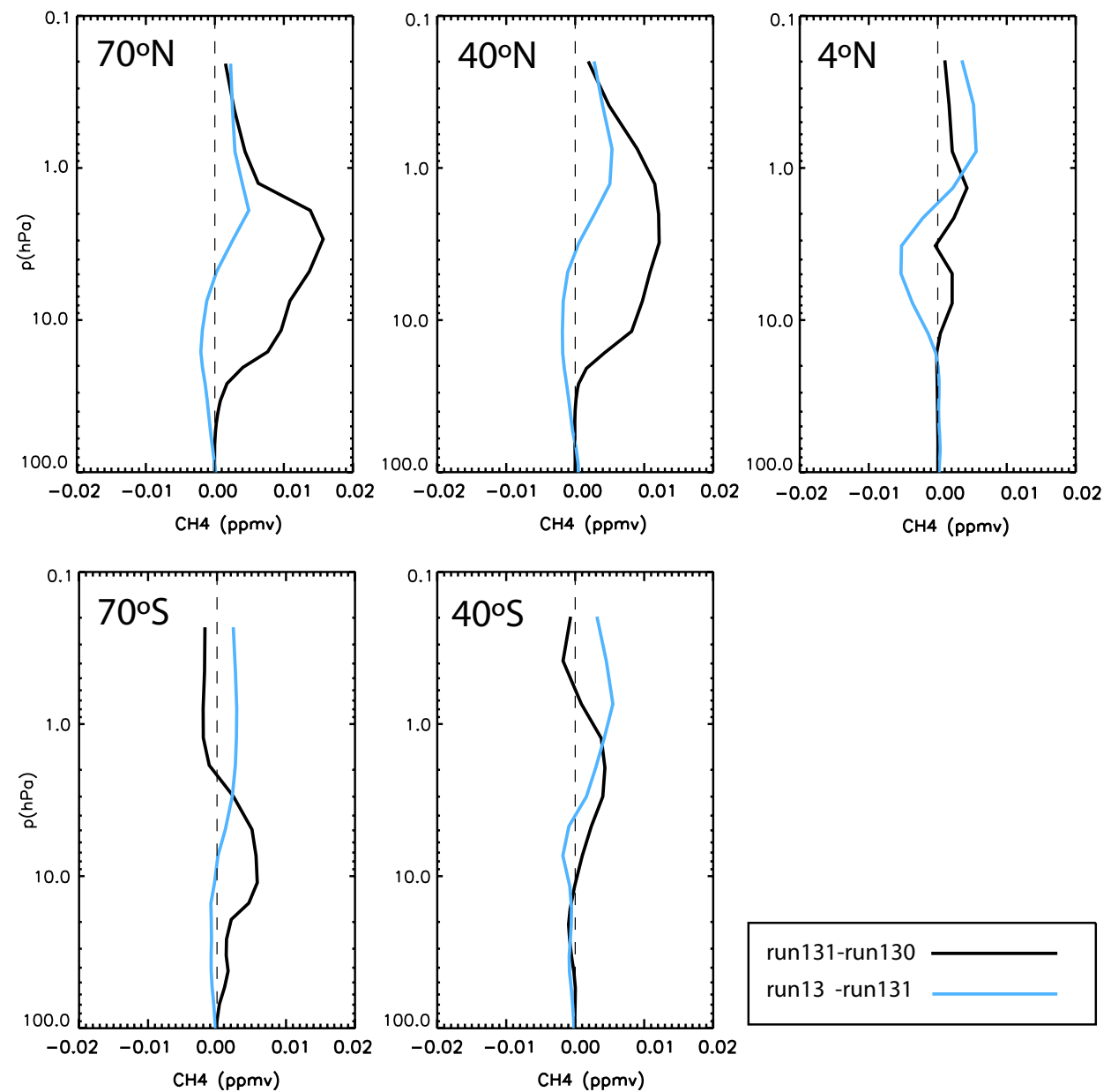

run131-run130

run13 -run131

Fig. 7. Annual average (year 2000) of the profiles for $\mathrm{CH}_{4}$ differences (ppmv) between run 131 and run130 (black line) and between run13 and run131 (blue line). Run13 uses the full parameterisation as in Eq. (12), run130 uses only the first term ( $\mathrm{c}_{0}$ in Eq. (12)) and run131 uses only the $\mathrm{c}_{0}$ and $\mathrm{c}_{1}$ terms of the scheme. All runs are driven by ERA- 40 reanalyses.

a significant noise reduction (e.g. Liu et al., 2010; Ploeger et al., 2011), in agreement with our comparison in Fig. 6.

\section{Stratospheric $\mathrm{H}_{2} \mathrm{O}$ distributions from CoMeCAT}

\subsection{CoMeCAT $\mathrm{H}_{2} \mathrm{O}$ distributions within the CTM}

To obtain CoMeCAT water distributions with the SLIMCAT CTM, the humidity field from the ECMWF analysis is used in the troposphere, while in the stratosphere the relation described in Eq. (14) is used to obtain $\mathrm{H}_{2} \mathrm{O}$ tendencies from CoMeCAT. In the tropics $\left(15^{\circ} \mathrm{S}-15^{\circ} \mathrm{N}\right) \mathrm{H}_{2} \mathrm{O}$ is taken from the ECMWF analyses for levels below the level at which the minimum temperature is reached; outside the tropics the ECMWF $\mathrm{H}_{2} \mathrm{O}$ field is used when the absolute potential vorticity (PV) is less than $2 \mathrm{PVU}^{2}$ and the potential temperature $(\theta)$ less than $380 \mathrm{~K}$, or if $\theta$ is less than $300 \mathrm{~K}$. For all other

\footnotetext{
${ }^{2} \mathrm{PVU}$ is potential vorticity unit and its value is $1 \mathrm{PVU}=10^{-6} \mathrm{~m}^{2} \mathrm{~s}^{-1} \mathrm{~K} \mathrm{~kg}^{-1}$.
}

levels we use the CoMeCAT scheme to compute the stratospheric tendencies of water vapour.

Figure 8a shows the $\mathrm{H}_{2} \mathrm{O}$ cross section (annual average 2000) from CoMeCAT. The overall variability is well captured by the CoMeCAT approach; the best agreement with HALOE (Fig. 8e) is found over NH high and mid-latitudes. In the LS, CoMeCAT shows a wet bias of $\sim 0.6 \mathrm{ppmv}$ in the range $100-50 \mathrm{hPa}$, and then agreement in the middle stratosphere $(50-3 \mathrm{hPa})$ is very good for all latitudes, except over southern high latitudes, where CoMeCAT $\mathrm{H}_{2} \mathrm{O}$ is up to $0.8 \mathrm{ppmv}$ larger than observed by HALOE. Above $3 \mathrm{hPa}$, CoMeCAT again produces larger concentrations (up to $0.5 \mathrm{ppmv}$ ). The discrepancy over southern high latitudes between CoMeCAT and HALOE in the LS is most likely due to the lack of Antarctic dehydration in the CoMeCAT scheme. 

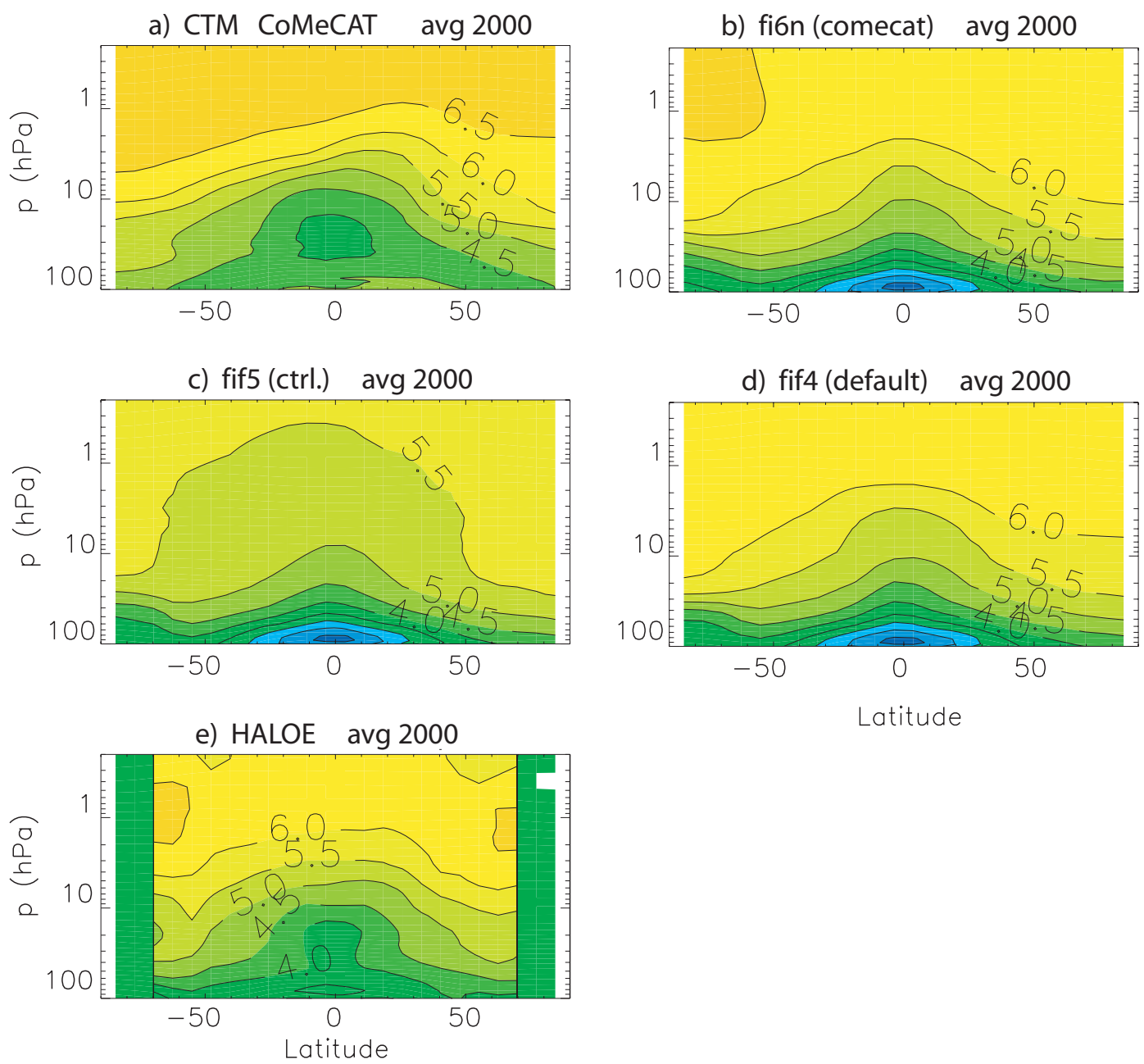

Fig. 8. $\mathrm{H}_{2} \mathrm{O}$ (ppmv) cross sections averaged over year 2000 obtained from (a) CoMeCAT in the SLIMCAT run13, (b) CoMeCAT in ECMWF run fi6n, (c) ECMWF control run fif5, (d) ECMWF default scheme in run fif4 and (e) HALOE instrument. Colour scale goes from larger concentrations (orange) to smaller concentrations (dark blue). Contour interval is $0.5 \mathrm{ppmv}$. HALOE observations are available for the latitudinal range $80^{\circ} \mathrm{S}-80^{\circ} \mathrm{N}$.

\subsection{CoMeCAT $\mathrm{H}_{2} \mathrm{O}$ distributions in the GCM}

The default ECMWF (currently operational) stratospheric water scheme and $\mathrm{H}_{2} \mathrm{O}$ obtained from the $\mathrm{CoMeCAT} \mathrm{CH}_{4}$ in the ECMWF runs have been compared against HALOE observations and $\mathrm{H}_{2} \mathrm{O}$ from CoMeCAT in the CTM. The same ECMWF runs used to obtain results in Sect. 3.3 have been used to parameterise stratospheric $\mathrm{H}_{2} \mathrm{O}$ (Table 2). The initial value for the $\mathrm{H}_{2} \mathrm{O}$ tracer in the ECMWF runs was $7.0 \times 10^{-6}-2\left[\overline{\mathrm{CH}_{4}}\right]$. Figure 8 shows $\mathrm{H}_{2} \mathrm{O}$ cross sections averaged over the year 2000 obtained from CoMeCAT in the ECMWF model (run fi6n). Also shown in the same figure are $\mathrm{H}_{2} \mathrm{O}$ from the default ECMWF scheme (run fif4) and from an ECMWF control run (fif5) in which no water source scheme is used in the stratosphere.

\subsubsection{ECMWF default $\mathrm{H}_{2} \mathrm{O}$ scheme}

The ECMWF stratospheric $\mathrm{H}_{2} \mathrm{O}$ currently comes from a parameterisation based on a fixed profile of water vapour observed lifetime (e.g. Dethof, 2003). This scheme does not include any latitudinal variation, relying on the accuracy of the Brewer-Dobson circulation to get the correct amount of $\mathrm{H}_{2} \mathrm{O}$ increase in the stratosphere due to $\mathrm{CH}_{4}$ oxidation. Figure 8d shows $\mathrm{H}_{2} \mathrm{O}$ from an ECMWF run (fif4) using this default stratospheric water scheme. At high latitudes in the upper levels (above $5 \mathrm{hPa}$ ) fif $4 \mathrm{H}_{2} \mathrm{O}$ concentrations are around 0.5 ppmv smaller than HALOE. One control run has also been carried out (run fif5) in which the source of water in the stratosphere has been switched off (Fig. 8c). It can be seen that the $\mathrm{H}_{2} \mathrm{O}$ field would be far too low in the stratosphere in the absence of a source parameterisation; up to 1.5 ppmv are added by the default ECMWF $\mathrm{H}_{2} \mathrm{O}$ scheme, 
which also makes the concentration gradients realistic. Compared to the CTM run and to HALOE observations, the ECMWF $\mathrm{H}_{2} \mathrm{O}$ distributions show a negative bias in the tropics around $100 \mathrm{hPa} ; \mathrm{H}_{2} \mathrm{O}$ in the ECMWF run is $2.5 \mathrm{ppmv}$ smaller than in the CTM run (Fig. 8a) and 2.0 ppmv smaller than HALOE observations (Fig. 8e). This bias is present in all three ECMWF simulations, independent of the scheme used to obtain stratospheric $\mathrm{H}_{2} \mathrm{O}$, which indicates a characteristic of this version of the ECMWF GCM that will require further investigation.

\subsubsection{ECMWF new $\mathrm{H}_{2} \mathrm{O}$ scheme from CoMeCAT}

The distribution of water from the CoMeCAT scheme implemented in the ECMWF model (run fi6n) is shown in Fig. 8b. Compared to the performance of the same scheme in SLIMCAT (Fig. 8a), the ECMWF run shows smaller $\mathrm{H}_{2} \mathrm{O}$ values (up to $0.5 \mathrm{ppmv}$ lower above $10 \mathrm{hPa}$ ). The SLIMCAT run is closer to the HALOE distribution (Fig. 8e). In the ECMWF model, CoMeCAT produces vertical distributions of $\mathrm{H}_{2} \mathrm{O}$ similar to those from the IFS default scheme, except at high levels (above $10 \mathrm{hPa}$ ), where CoMeCAT can simulate up to 0.5 ppmv more $\mathrm{H}_{2} \mathrm{O}$ at some latitudes (Fig. 8). The differences between the CoMeCAT $\mathrm{H}_{2} \mathrm{O}$ distributions in the CTM and the ECMWF runs partly arise from the fact that firn comes from the free-running GCM while the SLIMCAT run is forced by 6-hourly ERA-40 analyses. This last factor conditions the concentrations entering through the tropopause, as it is the analysed humidity field that is adopted for the troposphere in the CTM runs. ERA-40 shows a $10 \%$ wet bias with respect to HALOE in the LS (Oikonomou and O'Neill, 2006). The too large $\mathrm{H}_{2} \mathrm{O}$ concentrations that enter the CoMeCAT scheme from the tropopause are accumulated throughout the entire stratosphere, causing the CoMeCAT CTM run to show larger concentrations than HALOE (Fig. 8a). On the other hand, the problems shown by the ECMWF default $\mathrm{H}_{2} \mathrm{O}$ scheme in previous analysis versions, e.g. in ERA-40 (Uppala et al., 2005), have been partially overcome due to a more realistic transport in the more recent ECMWF model versions (like the one used for this run fif4).

\section{Effects of GCM nudging on stratospheric tracers transport}

The use of nudged GCMs is increasing over recent years as a potential way to make these models closer to the real atmosphere (Jeuken et al., 1996; Schmidt et al., 2006; Telford et al., 2008; Douville, 2009). Such an approach consists of relaxing, or nudging, the GCM dynamical fields towards meteorological (re)analyses so that, if $M$ is the model operator and $G$ the nudging parameter, the evolution of a certain model variable $\boldsymbol{x}$ is given by

$$
\frac{\partial \boldsymbol{x}}{\partial t}=M\left(\boldsymbol{x}+G\left(\boldsymbol{x}_{\mathrm{an}}-\boldsymbol{x}\right)\right),
$$

Nudging improves temperature and fast horizontal wind fields in the GCM; however, the impact of nudging on the slow stratospheric meridional circulation has not been widely tested yet. Until now, most published studies on GCM nudging have focused on nudging effects on dynamical fields (e.g. Telford et al., 2008; Douville, 2009), neglecting the effects this has on the distribution of chemical tracers in the stratosphere. A few studies have evaluated the ability of nudged models to simulate the distribution of stratospheric tracers compared to observations (e.g. van Aalst et al., 2004; Jöckel et al., 2006; Lelieveld et al., 2007). Here we evaluate nudging effects on stratospheric circulation thanks to the inclusion of CoMeCAT as a suitable stratospheric transport tracer in the ECMWF GCM. The CoMeCAT tracer has allowed us to evaluate, in online runs, the effects that nudging the GCM to reanalyses has on stratospheric transport compared to the free-running GCM and to corresponding offline CTM runs. To the best of our knowledge, the present study is the first one to tackle this kind of comparison.

Two nudged IFS simulations have been performed for this transport evaluation: experiments fh 22 and fh 23 (Table 2) have been produced with the same GCM version and the same CoMeCAT parameterisation as the free-running GCM simulation fi6n. However, in fh22 the dynamical variables are relaxed to ERA-40 values (year 2000), and in fh23 they are relaxed to ERA-Interim.

All dynamical variables are nudged and the nudging is applied to the full vertical range of the IFS model. The relaxation is done instantaneously every $6 \mathrm{~h}$. Even if this nudging procedure is stronger than the nudging usually applied within other GCMs, it needs to be taken into account that we are nudging the ECMWF GCM with ECMWF reanalyses. The fact that the GCM is the same one used to produce the reanalyses helps to reduce inconsistencies, which in other cases needs to be done by applying weaker nudging strategies.

Figure 9 shows $\mathrm{CoMeCAT} \mathrm{CH}_{4}$ annually averaged cross sections for the free-running experiment firn and the nudged runs fh22 and fh23; results from the CoMeCAT-SLIMCAT run13 (Table 1) and the CoMeCAT-TOMCAT run14 (ERA40) and run15 (ERA-Interim) are also included. Compared to the free-running firn, fh22 results in larger $\mathrm{CH}_{4}$ concentrations at almost all levels and latitudes. At the uppermost levels (above $1 \mathrm{hPa}$ ) the GCM run nudged to ERA-40 produces between 0.2 (at high latitudes) and $0.3 \mathrm{ppmv}$ (at the tropics) more than fi6n. This is similar to the effect found when using CoMeCAT in the TOMCAT $(\sigma-p)$ run forced by ERA-40 (Fig. 9c), compared to the SLIMCAT run (Fig. 9a). These too large $\mathrm{CH}_{4}$ values in the upper stratosphere are related to the excessive vertical transport exhibited by ERA-40 in TOMCAT simulations (Monge-Sanz et al., 2007, 2012). Therefore, our results show that nudging is bringing the GCM 

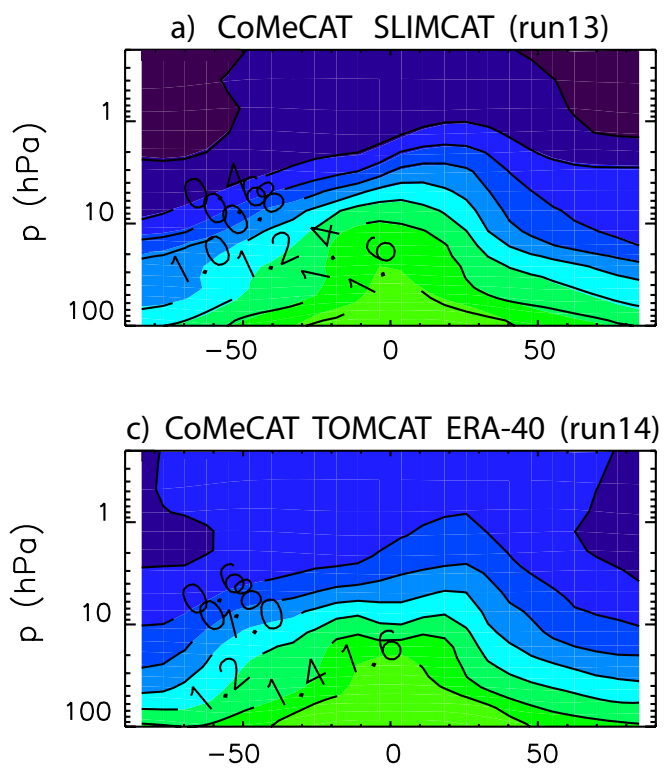

e) CoMeCAT TOMCAT ERA-Int (run15)

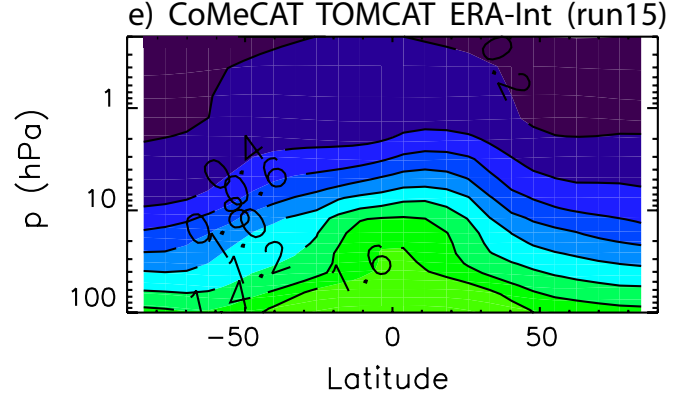

b) CoMeCAT free IFS (fi6n)

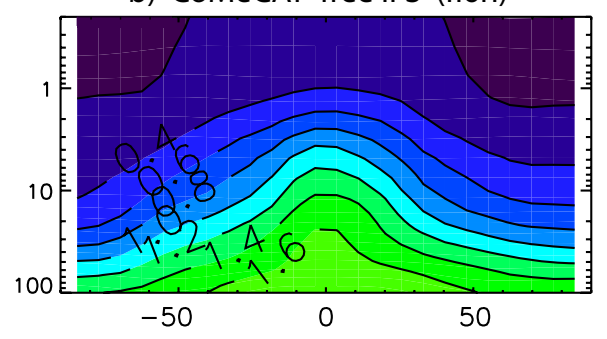

d) CoMeCAT IFS nudged ERA-40 (fh22)

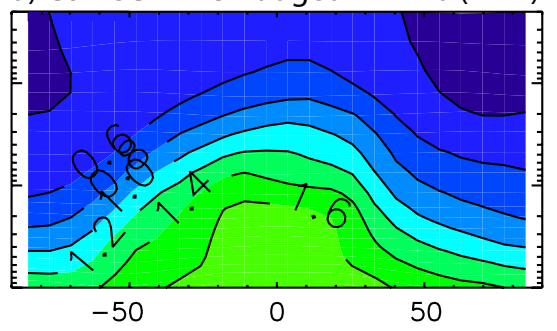

f) CoMeCAT IFS nudged ERA-Int (fh23)

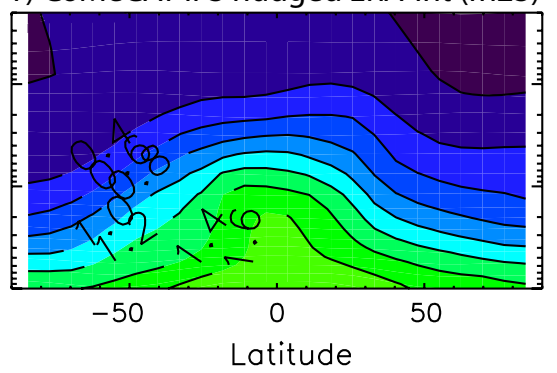

Fig. 9. Annually averaged zonal $\mathrm{CH}_{4}$ distributions (ppmv) for year 2000 from the CoMeCAT tracer in (a) the SLIMCAT CTM run13, (b) the free-running GCM fi6n, (c) the TOMCAT run14 forced by ERA-40 fields, (d) the GCM run fh22 nudged to ERA-40, (e) the TOMCAT run 15 forced by ERA-Interim and (f) the GCM run fh23 nudged to ERA-Interim. Colour scale goes from larger concentrations (dark green) to smaller concentrations (dark blue). Contour interval is $0.20 \mathrm{ppmv}$.

closer to the transport features in ERA-40, with the associated known problems. The TOMCAT run forced by ERAInterim brings the $\mathrm{CH}_{4}$ distribution closer to that from the SLIMCAT run. Similarly, the GCM run nudged to ERAInterim (fh23) is in better agreement with the SLIMCAT run and the free-running GCM than fh22. This also indicates that the effect the too fast stratospheric transport in ERA-40 had on stratospheric tracers is significantly improved in ERAInterim.

In the nudged GCM, an upper limit to the quality of the dynamical fields is set by the meteorological data used for the nudging: when ERA-40 fields are used, the nudged GCM shows the same problems as the offline CTM driven by the same ERA-40 fields, while the distribution of the stratospheric tracers improves in a similar way in the TOMCAT ERA-Interim run and in the GCM nudged to ERA-Interim fields. The experiments in this section therefore show not only the potential of CoMeCAT as an internal tracer for stratospheric transport but also provide an assessment of a
GCM nudged to the ERA-40 and ERA-Interim reanalyses. Our assessment shows that the GCM nudged to these meteorological series exhibits similar features to the CTM driven by the same meteorological fields, exposing the potential limitations of nudged GCM runs for tracer transport applications, compared to the less computationally expensive CTM runs.

\section{Stratospheric methane, radiation and temperature}

Methane is a strong greenhouse gas that warms the troposphere and middle/lower stratosphere, and cools the mesosphere/upper stratosphere. Despite this, many GCMs use only a fixed constant value for $\mathrm{CH}_{4}$ concentrations (e.g. Collins et al., 2006); that is, these models consider $\mathrm{CH}_{4}$ as a well-mixed gas, which is unrealistic above the tropopause. Using a simpler parameterisation approach than CoMeCAT, Curry et al. (2006) showed the impact that relaxing the wellmixed approximation for some greenhouse gases (GHGs) 
had in the stratosphere. They used the Canadian AGCM3 general circulation model (McFarlane et al., 1992) with a simplified treatment for the chemical loss of $\mathrm{N}_{2} \mathrm{O}, \mathrm{CH}_{4}$, CFC-11 and CFC-12. Curry et al. (2006) found a general cooling of the stratosphere compared to the use of wellmixed concentrations for these GHGs, mainly caused by the additional $\mathrm{H}_{2} \mathrm{O}$ resulting from the $\mathrm{CH}_{4}$ oxidation; they also found increases in temperature in the upper winter stratosphere (up to $8 \mathrm{~K}$ over the pole).

\subsection{Stratospheric temperatures}

In past versions of the IFS GCM, a global $\mathrm{CH}_{4}$ value of 1.72 ppmv was used by the ECMWF radiation scheme (Bechtold et al., 2009); such a value is typical of tropospheric levels, and was shown by Monge-Sanz (2008) to cause temperature biases in the upper stratosphere compared to the use of the CoMeCAT tracer coupled to the ECMWF radiation scheme. In the IFS version used in the present study, the default $\mathrm{CH}_{4}$ field included in the radiation scheme is a twodimensional climatology derived from the reanalysis of the Global and regional Earth-system Monitoring using Satellite and in-situ data project (GEMS, Hollingsworth et al. 2008). In order to evaluate the impact that CoMeCAT has on the ECMWF temperature field, compared to the default climatology, CoMeCAT has been made interactive with the ECMWF radiation scheme, and temperature changes in the GCM have been examined. For this, three sets of simulations have been performed with the CoMeCAT parameterisation in IFS:

(i) one in which CoMeCAT $\mathrm{CH}_{4}$ is not interactive with the radiation scheme ( $\mathrm{ft} 46)$, and therefore the radiation scheme still sees the climatological GEMS $\mathrm{CH}_{4}$ fields;

(ii) one with $\mathrm{CoMeCAT} \mathrm{CH}_{4}$ interactive with the radiation scheme (ft5b);

(iii) one with $\mathrm{CoMeCAT} \mathrm{CH}_{4}$ interactive with the radiation scheme and with activated $\mathrm{CoMeCAT} \mathrm{CH}_{4}$ oxidation to $\mathrm{H}_{2} \mathrm{O}$ (ftjs).

Simulations $\mathrm{ft} 46$ and $\mathrm{ft} 5 \mathrm{~b}$ use the operational ECMWF $\mathrm{CH}_{4}$ oxidation to $\mathrm{H}_{2} \mathrm{O}$ as described in www.ecmwf.int/ research/ifsdocs/CY36r1/PHYSICS/IFSPart4.pdf. Each of these GCM simulations covers the period 1996-2000 and each $1 \mathrm{yr}$ run consists of four $1 \mathrm{yr}$ forecasts (with an additional spin-up period of 2 months) started $30 \mathrm{~h}$ apart: $1 \mathrm{Jan}$ uary at 00:00 UTC, 2 January at 06:00 UTC, 3 January at 12:00 UTC and 4 January at 18:00 UTC. The different starting hours (00:00, 06:00, 12:00 and 18:00 UTC) ensure that the diurnal cycle is properly sampled, minimising potential biases resulting from the fact that model output is archived every $24 \mathrm{~h}$. The radiation calculations are performed every hour, which is also the time step of the model integration, using the ECMWF operational radiation scheme (Morcrette et al., 2008).

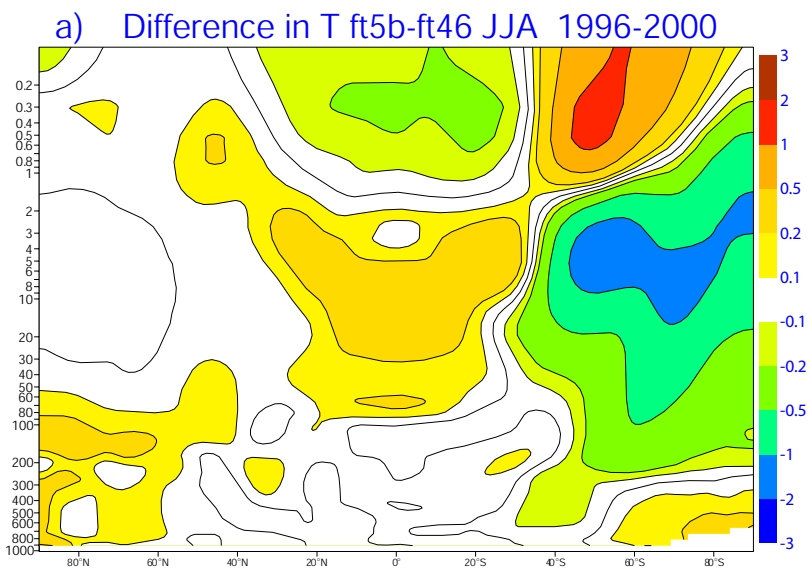

b) Difference in T ftjs-ft5b JJA 1996-2000

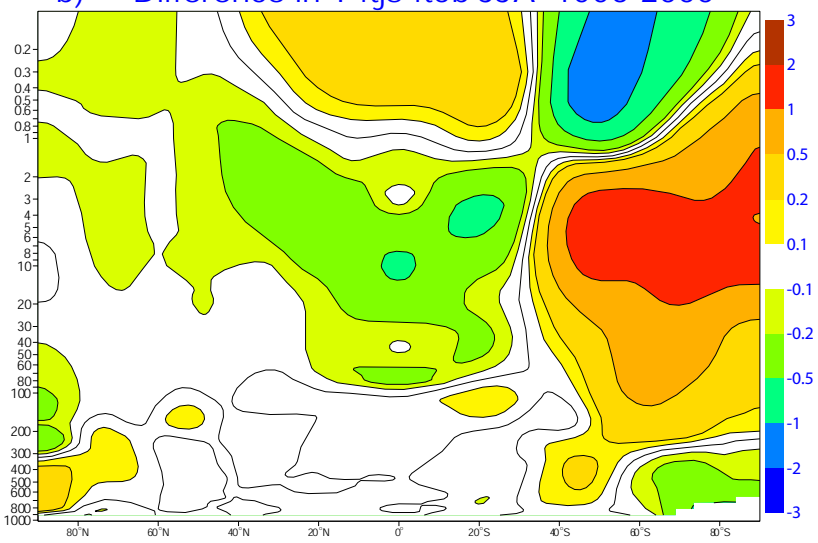

Fig. 10. Differences in temperature $(\mathrm{K})$ averaged over June-JulyAugust (JJA) 1996-2000 between the ECMWF runs (a) ft5b (CoMeCAT $\mathrm{CH}_{4}$ in the radiation scheme) and ft46 (GEMS $\mathrm{CH}_{4}$ climatology in the radiation scheme); (b) run ftjs (CoMeCAT $\mathrm{CH}_{4}$ and $\mathrm{H}_{2} \mathrm{O}$ in the radiation scheme) and run $\mathrm{ft} 5 \mathrm{~b}\left(\mathrm{CoMeCAT} \mathrm{CH}_{4}\right.$ in the radiation scheme). Colour scale goes from most negative differences (dark blue) to most positive differences (dark red).

Figure 10a shows the June-July-August (JJA) averaged differences in temperature in the ECMWF model using the default operational ECMWF $\mathrm{CH}_{4}$ climatology (run $\mathrm{ft} 46$ ) in the IFS radiation scheme and using the $\mathrm{CH}_{4}$ distributions from the CoMeCAT tracer (run $\mathrm{ft} 5 \mathrm{~b}$ ). Absorption by $\mathrm{CH}_{4}$ is considered both in the shortwave (SW) and the longwave (LW) in these runs. With CoMeCAT temperature increases over the tropics and subtropics $\left(40^{\circ} \mathrm{N}-40^{\circ} \mathrm{S}\right)$ between 1 and $100 \mathrm{hPa}$; temperature in this region is up to $0.5 \mathrm{~K}$ warmer than with the IFS default climatology. Larger temperature differences are found over the winter hemisphere, where cooling of up to $2.0 \mathrm{~K}$ appears over southern high latitudes around $5 \mathrm{hPa}$ when using the prognostic CoMeCAT $\mathrm{CH}_{4}$. Even if the dynamical variability is large in the SH for these months, performing a $t$ test reveals that the signal is statistically significant for $\mathrm{SH}$ lower stratospheric regions at high 
latitudes. The value of the differences outside the winter high latitudes is within the standard deviation of temperature for the 1996-2000 period over this region for the two IFS runs. To obtain more information, longer runs would be required, which were beyond the resources available for this study. Nevertheless, the temperature differences in Fig. 10a agree with the differences in the $\mathrm{CH}_{4}$ fields of both runs ( $\mathrm{ft} 5 \mathrm{~b}-\mathrm{ft} 46$ ) shown in Fig. 11. The CoMeCAT $\mathrm{CH}_{4}$ concentrations for the JJA average over the period 1996-2000 are larger than in the GEMS climatology for the tropics at levels between 0.5 and $100 \mathrm{hPa}$ (Fig. 11); larger concentrations result in warmer temperatures for that region, and a corresponding temperature effect of opposite sign above the same region (as it can be seen in Fig. 10a). Analogously, the smaller CoMeCAT $\mathrm{CH}_{4}$ stratospheric concentrations over the $\mathrm{SH}$, reinforced by the larger $\mathrm{CoMeCAT} \mathrm{CH}_{4}$ tropospheric values, have a cooling effect with respect to the use of the GEMS climatology in the low and mid-stratosphere.

Figure 10b shows the June-July-August (JJA) averaged differences in temperature in the ECMWF model when both $\mathrm{CH}_{4}$ and $\mathrm{H}_{2} \mathrm{O}$ from CoMeCAT are interactive with the radiation scheme (run ftjs) and when only $\mathrm{CoMeCAT} \mathrm{CH}_{4}$ interacts with radiation (run ft5b). The effect the $\mathrm{H}_{2} \mathrm{O}$ concentrations from $\mathrm{CoMeCAT} \mathrm{CH}_{4}$ oxidation have on temperature is of up to $1.0 \mathrm{~K}$ decrease over the tropical mid/low stratosphere, and a warming of the SH mid/high latitudes between 1 and $200 \mathrm{hPa}$. The temperature differences in Fig. 10b are larger than the values for the standard deviation of temperature of the corresponding runs (ftjs, $\mathrm{ft} 5 \mathrm{~b}$ ), which shows that the effects on temperature from the combined CoMeCAT $\mathrm{CH}_{4}$ and $\mathrm{H}_{2} \mathrm{O}$ fields produce a signal stronger than the model internal variability. These results highlight the advantage of including schemes for radiative gases that are consistent with each other (like CoMeCAT $\mathrm{CH}_{4}$ and $\mathrm{H}_{2} \mathrm{O}$ ), compared to the use of different climatologies/schemes for each gas (where effects can be cancelled or enhanced for the wrong reasons).

\subsection{Radiative forcing}

Further calculations of radiative effects of the CoMeCAT $\mathrm{CH}_{4}$ distribution have been performed with the offline version of the Edwards-Slingo (E-S) radiative transfer model (Edwards and Slingo, 1996) with a $2.5^{\circ}$ horizontal resolution and 23 pressure levels. The vertical levels in our E-S model runs match those of the original archiving of ERA40 fields on pressure levels ${ }^{3}$. This state-of-the-art radiative model uses nine bands in the longwave and six bands in the shortwave and a delta-Eddington two-stream scattering solver at all wavelengths. The E-S model employs a monthly averaged climatology based on ERA-40 data for temperature, ozone and water vapour. Monthly mean climatological cloud fields and surface albedo (averaged over the period 1983-

\footnotetext{
${ }^{3}$ www.ecmwf.int/products/data/archive/descriptions/e4/oper/ an/pl/2.5/index.html
}

Difference in CH4 (1.E-8 kg/kg) JJA 1996-2000

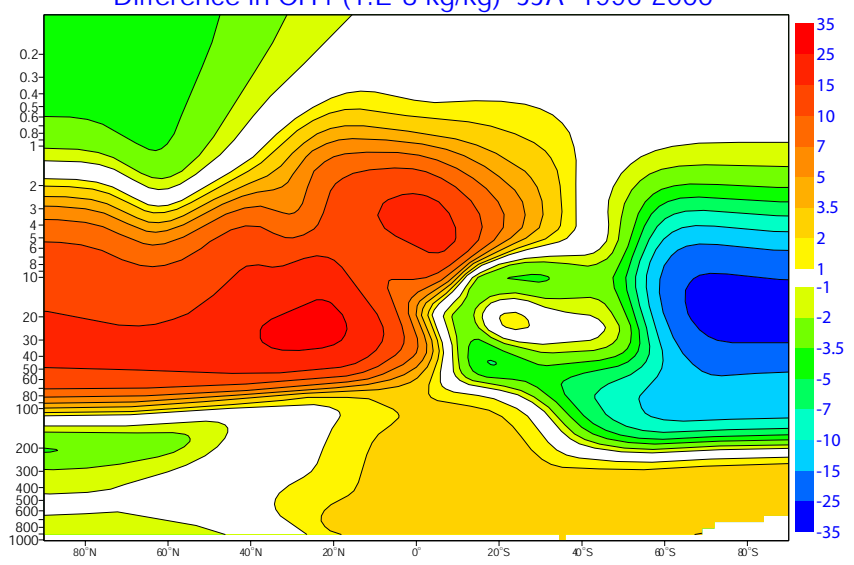

Fig. 11. Differences in the $\mathrm{CH}_{4}$ concentrations $\left(10^{-8} \mathrm{~kg} \mathrm{~kg}^{-1}\right)$ between the CoMeCAT distribution and ECMWF GEMS climatology in the radiation scheme, averaged for June-July-August (JJA) 19962000. Colour scale goes from most negative differences (dark blue) to most positive differences (dark red).

2005) are taken from the International Satellite Cloud Climatology Project (ISCCP) archive (Rossow and Schiffer, 1999). Clouds are added to three vertical levels, corresponding to low, middle and high clouds. The version of the E-S model we use here has been recently tested in Forster et al. (2011).

The CoMeCAT radiative effect (RE) has been evaluated for each calendar month by taking the differences between three runs of the E-S radiation code: (i) one control run ("ctrl") using a global 3-D constant $\mathrm{CH}_{4}$ value of $1.80 \mathrm{ppmv}$ for $\mathrm{CH}_{4}$ (the same for every calendar month), (ii) one perturbed run ("come") taking the $\mathrm{CH}_{4}$ distribution from the CoMeCAT $\mathrm{CH}_{4}$ field in the CTM run13 and (iii), one second perturbed run ("gems") using the same $\mathrm{CH}_{4}$ GEMS climatology as the ECMWF model currently uses by default.

Figure 12 shows the annual mean values of the net RE differences between the perturbed and the control radiation runs. The differences have been calculated at the tropopause after allowing for stratospheric temperatures to readjust to radiative equilibrium, using the fixed dynamical heating approximation (Ramanathan and Dickinson, 1979; Forster and Shine, 1997). Changing from the constant $1.80 \mathrm{ppmv}$ value used in the "ctrl" run to the much more realistic distribution in the stratosphere for the "come" run results in global cooling; negative differences are found in all regions, with a global average value of $-11.0 \mathrm{~mW} \mathrm{~m}^{-2}$ (Fig. 12a). The value of $1.80 \mathrm{ppmv}$ is the value used by the CoMeCAT CTM runs in the troposphere. In this way, with these two runs of the E-S model ("come"-"ctrl"), we can evaluate RE differences due only to stratospheric $\mathrm{CH}_{4}$. These differences are of the same order of magnitude as those obtained when including aircraft contrails' formation in the radiative model (Rap et al., 2010). Our results imply that RE calculations using a well-mixed approximation that overestimates stratospheric 

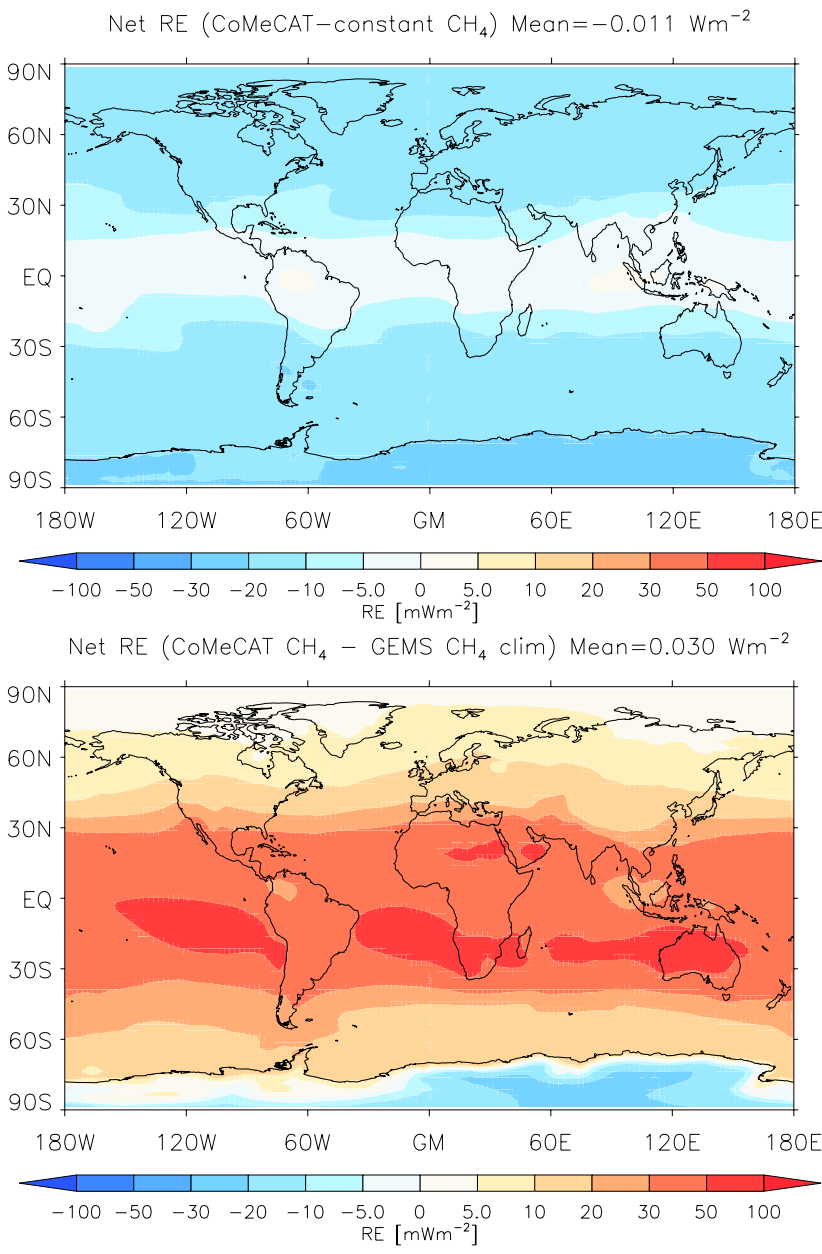

Fig. 12. Annually averaged net radiative forcing $\left(\mathrm{mW} \mathrm{m}^{-2}\right)$ in-

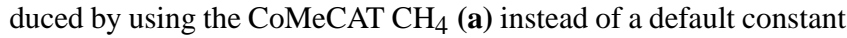
value of $1.80 \mathrm{ppmv}$ in the Edwards-Slingo (E-S) radiation model (upper panel) and (b) instead of the GEMS climatology for $\mathrm{CH}_{4}$ in the E-S model (bottom panel). See main text (Sect. 6.2) for details about the model runs used for these calculations. In the colour scale, blue is for negative radiative effect (cooling), and red for positive radiative effect (warming).

methane concentrations will overestimate surface warming globally. The use of a constant $\mathrm{CH}_{4}$ profile is still the default option in offline radiative models like the E-S model, which are widely used for climate research. Figure 12a therefore shows the importance of an improved stratosphere in radiative forcing calculations, with respect to the standards currently used for climate studies.

Figure $12 \mathrm{~b}$ shows the annual mean values of the net RE differences, between the "come" run using the CoMe$\mathrm{CAT} \mathrm{CH}_{4}$ field and the "gems" run using the same $\mathrm{CH}_{4}$ GEMS climatology as ECMWF currently uses. There is an overall warming effect at all latitudes with a global mean average value of $30 \mathrm{~mW} \mathrm{~m}^{-2}$; maximum values of up to $100 \mathrm{~mW} \mathrm{~m}^{-2}$ are found over the tropics. The only exception

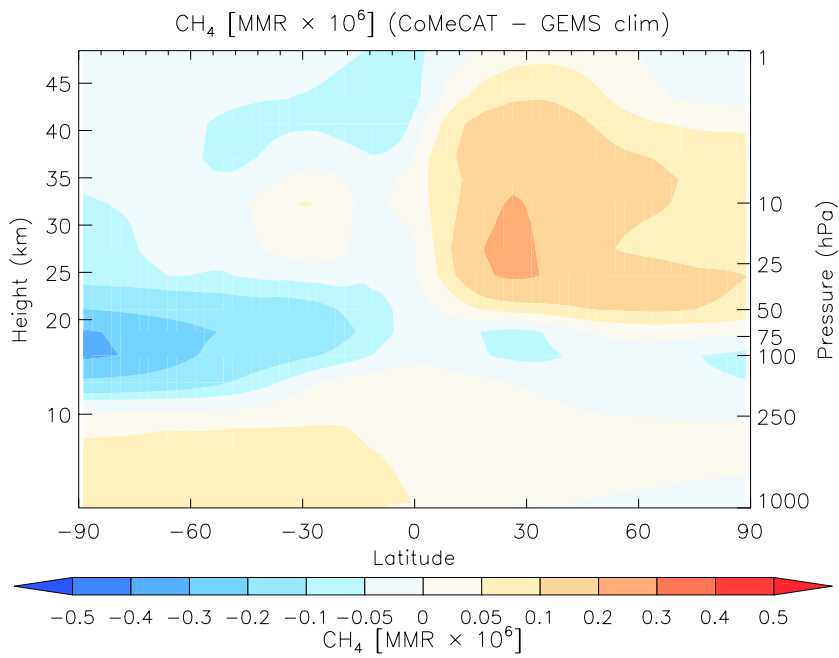

Fig. 13. Annually averaged cross section for the differences in the $\mathrm{CH}_{4}$ concentrations $\left(10^{-6} \mathrm{~kg} \mathrm{~kg}^{-1}\right)$ between the CoMeCAT distribution and the ECMWF GEMS climatology; these differences correspond to the radiative effect (RE) shown in the lower panel of Fig. 12. Colour scale goes from most negative differences (dark blue) to most positive differences (dark red).

to the warming is the Antarctic continent, where cooling of up to $30 \mathrm{~mW} \mathrm{~m}^{-2}$ is obtained when using the CoMeCAT field instead of the GEMS climatology. The distribution of these radiative effects is very dependent on the altitude at which the differences in $\mathrm{CH}_{4}$ concentrations between the two runs are found (Riese et al., 2012). Figure 13 shows the cross section of $\mathrm{CH}_{4}$ differences corresponding to the calculations shown in Fig. 12b. Even if the largest differences between CoMeCAT and GEMS are found above $100 \mathrm{hPa}$ - that is, where the influence on radiative effects is not the largest (Riese et al., 2012) - such differences are still modifying the effects of the differences in $\mathrm{CH}_{4}$ found in lower levels, including tropospheric levels. Results in Figs. 12b and 13 show that, in our runs, effects due to differences below the tropopause are compensated (or enhanced) by the differences found in the $\mathrm{SH}$ lower stratosphere (or the $\mathrm{NH}$ mid-stratosphere).

\section{Conclusions}

A new $\mathrm{CH}_{4}$ parameterisation scheme (CoMeCAT) has been developed for the stratosphere, and tested within a 3-D CTM and a 3-D GCM. The scheme has the advantage of parameterising both stratospheric $\mathrm{CH}_{4}$ and $\mathrm{H}_{2} \mathrm{O}$ in a consistent and efficient way.

The CoMeCAT $\mathrm{CH}_{4}$ scheme performs well in the TOMCAT/SLIMCAT CTM, showing very good agreement with observations from HALOE and with the CTM full-chemistry field. The largest differences with observations are found at high latitudes, especially in the $\mathrm{SH}$, where CoMeCAT (and full-chemistry) runs with ERA-40 underestimate $\mathrm{CH}_{4}$ 
compared to HALOE by up to $0.3 \mathrm{ppmv}$ at altitudes around $10 \mathrm{hPa}$. CoMeCAT also performs well in the ECMWF GCM, producing realistic $\mathrm{CH}_{4}$ distributions. The $\mathrm{CH}_{4}$ time tendency obtained from CoMeCAT has been used in both models (CTM and GCM) to parameterise the source of stratospheric water. The $\mathrm{H}_{2} \mathrm{O}$ distributions obtained from CoMeCAT in the CTM runs are in good agreement with HALOE observations, except for a wet bias in the LS region of $\sim 0.6$ ppmv. This is at least partly due to the use of ERA-40 humidity values in the troposphere, which show a wet bias at the tropopause. In the ECMWF model the CoMeCAT water approach performs well. ECMWF CoMeCAT $\mathrm{H}_{2} \mathrm{O}$ distributions show realistic spatial variability and good agreement with HALOE observations, except for a dry bias in the tropical lower stratosphere (of up to $2.0 \mathrm{ppmv}$ ).

The CoMeCAT scheme has also provided the ECMWF $\mathrm{GCM}$ with a suitable tracer $\left(\mathrm{CH}_{4}\right.$ tracer) for internal tests of stratospheric transport. This has allowed us to compare, for the first time, stratospheric transport in the free-running ECMWF GCM, also in two nudged configurations of the GCM and in corresponding offline CTM runs. Nudging the GCM to ERA-40 analyses produced similar $\mathrm{CH}_{4}$ distributions to those obtained with the TOMCAT $(\sigma-\mathrm{p})$ run by ERA40. Nudging the GCM to ERA-Interim brought about improvements, compared to the nudging to ERA-40, similar to those obtained in the TOMCAT run driven by ERA-Interim instead of ERA-40 fields. These results show that a nudged GCM incorporates the advantages and deficiencies of the analyses used, and nudging a recent version of the ECMWF IFS to ERA-40 is not recommended for applications involving transport of stratospheric tracers. Our results also indicate that runs with nudged GCMs do not necessarily show improvement over cheaper offline CTM runs regarding the stratospheric transport of tracers.

CoMeCAT impacts on radiation and temperature have been explored with two different models. When using CoMeCAT interactively with the ECMWF radiation scheme, the new $\mathrm{CH}_{4}$ warms (up to $0.5 \mathrm{~K}$ ) the middle stratosphere over mid/low latitudes compared to the use of the default $\mathrm{CH}_{4}$ field from the GEMS climatology. Using also CoMeCAT $\mathrm{H}_{2} \mathrm{O}$ in the radiation scheme decreases temperature over the tropical mid/low stratosphere and warms most of the $\mathrm{SH}$ stratosphere outside the tropics. These results show the importance of using distributions of $\mathrm{CH}_{4}$ and $\mathrm{H}_{2} \mathrm{O}$ that are consistent with each other.

The CoMeCAT scheme is a more realistic treatment for stratospheric $\mathrm{CH}_{4}$ than previously included in ECMWF. As a next step, the effect of using CoMeCAT in conjunction with similar schemes for other GHGs (e.g. $\mathrm{N}_{2} \mathrm{O}$ and CFCs) in models like IFS should be investigated. In addition, including this type of $\mathrm{CH}_{4} / \mathrm{H}_{2} \mathrm{O}$ scheme in the ECMWF model would also enable the assimilation of $\mathrm{CH}_{4}$ concentrations to be used to constrain humidity analyses in the stratosphere. In this study we have not been able to test the performance of CoMeCAT in data assimilation runs of the ECMWF model due to limitations in resources available for this project; however, this remains as a future line of research. The CoMeCAT scheme is also a good option to represent stratospheric $\mathrm{CH}_{4}$ within the Monitoring Air Composition and Climate (MACC) project; this is now part of ongoing research at ECMWF.

The CoMeCAT scheme also opens new possibilities for climate studies. In spite of being the second-most important greenhouse gas, many climate models use only a fixed value for $\mathrm{CH}_{4}$ in the stratosphere. Including a realistic $\mathrm{CH}_{4}$ profile, with latitude dependence and linked to other model variables (like temperature), is expected to produce changes to radiative forcing results in climate models. In our study, including the CoMeCAT methane distribution in the offline Edwards-Slingo (E-S) state-of-the-art radiation model has had an effect on the calculated radiative forcing values of the same order of magnitude, but of different sign, as the incorporation of aircraft contrail formation. The use of CoMeCAT instead of the default well-mixed approximation in the stratosphere has reduced radiative forcing values by up to $30 \mathrm{~mW} \mathrm{~m}^{-2}$ over mid- and high latitudes, with a global annually averaged change of $-11.0 \mathrm{~mW} \mathrm{~m}^{-2}$. This implies that a realistic representation of vertical distribution of GHGs in the stratosphere is necessary to better constrain radiative forcing and climate warming projections. In this sense it can be said that the stratosphere plays a similar role to that played by the oceans: the stratosphere acts as a slowly evolving boundary for the troposphere, and a realistic description of stratospheric processes is key to increasing the accuracy of long-term climate predictions. In addition, Solomon et al. (2010) highlighted the need for better representations of stratospheric $\mathrm{H}_{2} \mathrm{O}$ in climate models to better simulate and interpret decadal surface warming trends; the CoMeCAT scheme could also contribute in this respect. The inclusion of realistic schemes for other GHGs, like $\mathrm{N}_{2} \mathrm{O}$ and CFCs, is expected to have the same type of effect as we have shown here for methane. The total net contribution of such parameterised stratospheric GHGs to temperature and radiation will need to be quantified. Future research should be done on the effects that realistic GHGs vertical distributions in the stratosphere have on temperature and radiative forcing calculations, and therefore on climate studies, as well as on the effects that a more realistic stratospheric composition has on seasonal prediction systems.

Acknowledgements. We thank Elias Hólm for valuable communications on the ECMWF $\mathrm{H}_{2} \mathrm{O}$ scheme and Piers Forster for helpful discussions on the interaction of the scheme with the GCM radiation. We are also grateful to Lindsay Lee for advice on statistical analysis and to Nigel Richards for help with data files. This work has been funded by the NERC Research Award NE/F004575/1, the EU GEOMON project and the IEF Marie Curie Fellowship PIEF-GA-2010-273531.

Edited by: W. Lahoz 


\section{References}

Austin, J., Wilson, J., Li, F., and Vömel, H.: Evolution of Water Vapor Concentrations and Stratospheric age-of-air in Coupled Chemistry-Climate Model Simulations, J. Atmos. Sci., 64, 905921, doi:10.1175/JAS3866.1, 2007.

Bates, D. R. and Nicolet, M.: The photochemistry of water vapour, J. Geophys. Res., 55, 301-327, 1950.

Bechtold, P., Orr, A., Morcrette, J.-J., Engelen, R., Flemming, J., and Janiskova, M.: Improvements in the stratosphere and mesosphere of the IFS, ECMWF Newsletter, 2009.

Brasseur, G. and Solomon, S.: Aeronomy of the Middle Atmosphere, Springer, Dordrecht, the Netherlands, 2005.

Bregman, B., Meijer, E., and Scheele, R.: Key aspects of stratospheric tracer modeling using assimilated winds, Atmos. Chem. Phys., 6, 4529-4543, doi:10.5194/acp-6-4529-2006, 2006.

Cariolle, D. and Déqué, M.: Southern Hemisphere Medium-Scale Waves and Total Ozone Disturbances in a Spectral General Circulation Model, J. Geophys. Res., 91, 10825-10846, 1986.

Cariolle, D. and Teyssèdre, H.: A revised linear ozone photochemistry parameterization for use in transport and general circulation models: Multi-annual simulations, Atmos. Chem. Phys., 7, 2183-2196, doi:10.5194/acp-7-2183-2007, 2007.

Chipperfield, M. P.: New version of the TOMCAT/SLIMCAT offline chemical transport model, Q. J. Roy. Meteorol. Soc., 132, 1179-1203, doi:10.1256/qj.05.51, 2006.

Chipperfield, M. P., Khattatov, B. V., and Lary, D. J.: Sequential assimilation of stratospheric chemical observations in a three-dimensional model, J. Geophys. Res., 107, doi:10.1029/2002JD002110, 2002.

Collins, W., Ramaswamy, V., Schwarzkopf, M., Sun, Y., Portmann, R., Fu, Q., Casanova, S., Dufresne, J.-L., Fillmore, D., Forster, P., Galin, V., Gohar, L., Ingram, W., Kratz, D., Lefebvre, M.-P., Li, J., Marquet, P., Oinas, V., Tsushima, Y., Uchiyama, T., and Zhong, W.: Radiative forcing by well-mixed greenhouse gases: Estimates from climate models in the Intergovernmental Panel on Climate Change (IPCC) Fourth Assessment Report (AR4), J. Geophys. Res., 111, D14, D14317, doi:10.1029/2005JD006713, 2006.

Curry, C. L., McFarlane, N. A., and Scinocca, J. F.: Relaxing the well-mixed greenhouse gas approximation in climate simulations: Consequences for stratospheric climate, J. Geophys. Res., 111, D8, D08104, doi:10.1029/2005JD006670, 2006.

Dee, D. P., Uppala, S. M., Simmons, A. J., Berrisford, P., Poli, P., Kobayashi, S., Andrae, U., Balmaseda, M. A., Balsamo, G., Bauer, P., Bechtold, P., Beljaars, A. C. M., van de Berg, L., Bidlot, J., Bormann, N., Delsol, C., Dragani, R., Fuentes, M., Geer, A. J., Haimberger, L., Healy, S., Hersbach, H., Hólm, E. V., Isaksen, L., Kållberg, P., Köhler, M., Matricardi, M., McNally, A. P., Monge-Sanz, B. M., Morcrette, J.-J., Peubey, C., de Rosnay, P., Tavolato, C., Thépaut, J.-N., and Vitart, F.: The ERAInterim reanalysis: Configuration and performance of the data assimilation system, Q. J. Roy. Meteorol. Soc., 137, 553-597, doi:10.1002/qj.828, 2011.

Dethof, A.: Aspects of modelling and assimilation for the stratosphere at ECMWF, SPARC Newsletter, 21, 2003.

Dethof, A. and Hólm, E. V.: Ozone assimilation in the ERA-40 reanalysis project, Q. J. Roy. Meteorol. Soc., 130, 2851-2872, 2004.
Douville, H.: Stratospheric polar vortex influence on Northern Hemisphere winter climate variability, Geophys. Res. Lett., 36, 18, L18703, doi:10.1029/2009GL039334, 2009.

Edwards, J. M. and Slingo, A.: Studies with a flexible new radiation code: I. Choosing a configuration for a large scale model, Q. J. Roy. Meteorol. Soc., 122, 689-720, doi:10.1002/qj.49712253107, 1996.

Eyring, V., Butchart, N., Waugh, D. W., Akiyoshi, H., Austin, J., Bekki, S., Bodeker, G. E., Boville, B. A., Brühl, C., Chipperfield, M. P., Cordero, E., Dameris, M., Deushi, M., Fioletov, V. E., Frith, S. M., Garcia, R. R., Gettelman, A., Giorgetta, M. A., Grewe, V., Jourdain, L., Kinnison, D. E., Mancini, E., Manzini, E., Marchand, M., Marsh, D. R., Nagashima, T., Newman, P. A., Nielsen, J. E., Pawson, S., Pitari, G., Plummer, D. A., Rozanov, E., Schraner, M., Shepherd, T. G., Shibata, K., Stolarski, R. S., Struthers, H., Tian, W., and Yoshiki, M.: Assessment of temperature, trace species, and ozone in chemistry-climate model simulations of the recent past, J. Geophys. Res., 111, D22, D22308, doi:10.1029/2006JD007327, 2006.

Feng, W., Chipperfield, M. P., Dorf, M., Pfeilsticker, K., and Ricaud, P.: Mid-latitude ozone changes: studies with a 3-D CTM forced by ERA-40 analyses, Atmos. Chem. Phys., 7, 2357-2369, doi:10.5194/acp-7-2357-2007, 2007.

Forster, P. M. and Shine, K.: Radiative forcing and temperature trends from stratospheric ozone changes, J. Geophys. Res., 102, 841-855, 1997.

Forster, P. M., Fomichev, V. I., Rozanov, E., Cagnazzo, C., Jonsson, A. I., Langematz, U., Fomin, B., Iacono, M. J., Mayer, B., Mlawer, E., Myhre, G., Portmann, R. W., Akiyoshi, H., Falaleeva, V., Gillett, N., Karpechko, A., Li, J., Lemennais, P., Morgenstern, O., Oberländer, S., Sigmond, M., and Shibata, K.: Evaluation of radiation scheme performance within chemistry climate models, J. Geophys. Res., 116, D10302, doi10.1029/2010JD015361, 2011.

Fueglistaler, S., Wernli, H., and Peter, T.: Tropical troposphereto-stratosphere transport inferred from trajectory calculations, J. Geophys. Res., 109, D03108, doi:10.1029/2003JD004069, 2004.

Gettelman, A., Hegglin, M. I., Son, S.-W., Kim, J., Fujiwara, M., Birner, T., Kremser, S., Rex, M., Añel, J. A., Akiyoshi, H., Austin, J., Bekki, S., Braesike, P., Brühl, C., Butchart, N., Chipperfield, M., Dameris, M., Dhomse, S., Garny, H., Hardiman, S. C., Jöckel, P., Kinnison, D. E., Lamarque, J. F., Mancini, E., Marchand, M., Michou, M., Morgenstern, O., Pawson, S., Pitari, G., Plummer, D., Pyle, J. A., Rozanov, E., Scinocca, J., Shepherd, T. G., Shibata, K., Smale, D., Teyssèdre, H., and Tian, W.: Multimodel assessment of the upper troposphere and lower stratosphere: Tropics and global trends, J. Geophys. Res., 115, D00M08, doi:10.1029/2009JD013638, 2010.

Harries, J. E., Russell, J. M., Tuck, A. F., Gordley, L. L., Purcell, P., Stone, K., Bevilacqua, R. M., Gunson, M., Nedoluha, G., and Traub, W. A.: Validation of measurements of water vapor from the Halogen Occultation Experiment (HALOE), J. Geophys. Res., 101, 10205-10216, 1996.

Hazeleger, W., Severijns, C., Semmler, T., Ştefánescu, S., Yang, S., Wang, X., Wyser, K., Dutra, E., Baldasano, J., Bintanja, R., Bougeault, P., Caballero, R., Ekman, A., Christensen, J., van den Hurk, B., Jimenez, P., Jones, C., Kållberg, P., Koenigk, T., McGrath, R., Miranda, P., van Noije, T., Palmer, T., Parodi, J., Schmith, T., Selten, F., Storelvmo, T., Sterl, A., Tapamo, H., 
Vancoppenolle, M., Viterbo, P., and Willén, U.: EC-Earth: A Seamless Earth-System Prediction Approach in Action, B. Am. Meteor. Soc., 91, 1357-1363, doi:10.1175/2010BAMS2877.1, 2010.

Hollingsworth, A., Engelen, R. J., Textor, C., Benedetti, A., Boucher, O., Chevallier, F., Dethof, A., Elbern, H., Eskes, H., Flemming, J., Granier, C., Kaiser, J. W., Morcrette, J.-J., Rayner, P. R., Peuch, V.-H., Rouil, L., Schultz, M. G., Simmons, A. J., and the GEMS Consortium: Toward a monitoring and forecasting system for atmospheric composition: the GEMS project., B. Am. Meteor. Soc., 89, 1147-1164, doi:10.1175/2008BAMS2355.1, 2008.

Jeuken, A., Siegmund, P., Heijboer, L., Feichter, J., and Bengtsson, L.: On the Potential of assimilating meteorological analyses in a global climate model for the purposes of model validation, J. Geophys. Res., 101, 16939-16950, 1996.

Jöckel, P., Tost, H., Pozzer, A., Brühl, C., Buchholz, J., Ganzeveld, L., Hoor, P., Kerkweg, A., Lawrence, M., Sander, R., Steil, B., Stiller, G., Tanarhte, M., Taraborrelli, D., van Aardenne, J., and Lelieveld, J.: The atmospheric chemistry general circulation model ECHAM5/MESSy1: consistent simulation of ozone from the surface to the mesosphere, Atmos. Chem. Phys., 6, 50675104, doi:10.5194/acp-6-5067-2006, 2006.

Jones, R. L. and Pyle, J. A.: Observations of $\mathrm{CH}_{4}$ and $\mathrm{N}_{2} \mathrm{O}$ by the Nimbus 7 SAMA: A comparison with in situ data and twodimensional numerical model calculations, J. Geophys. Res., 89, 5263-5279, 1984.

Kinnersley, J. S. and Harwood, R. S.: An isentropic twodimensional model with an interactive parameterization of dynamical and chemical planetary wave fluxes, Q. J. Roy. Meteorol. Soc., 119, 1167-1193, 1993.

Kouker, W.: Towards the Prediction of Stratospheric Ozone (TOPOZ III), Scientific Report. EC Contract EVK2-CT-200100102, European Commission, Brussels, Belgium, 2005.

Krüger, K., Tegtmeier, S., and Rex, M.: Long-term climatology of air mass transport through the Tropical Tropopause Layer (TTL) during NH winter, Atmos. Chem. Phys., 8, 813-823, doi:10.5194/acp-8-813-2008, 2008.

Lelieveld, J., Brühl, C., Jöckel, P., Steil, B., Crutzen, P. J., Fischer, H., Giorgetta, M. A., Hoor, P., Lawrence, M. G., Sausen, R., and Tost, H.: Stratospheric dryness: model simulations and satellite observations, Atmos. Chem. Phys., 7, 1313-1332, doi:10.5194/acp-7-1313-2007, 2007.

Le Texier, H., Solomon, S., and Garcia, R. R.: The role of molecular hydrogen and methane oxidation in the water vapour budget of the stratosphere, Q. J. Roy. Meteorol. Soc., 114, 281-295, 1988.

Liu, Y. S., Fueglistaler, S., and Haynes, P. H.: Advectioncondensation paradigm for stratospheric water vapor, J. Geophys. Res., 115, D24307, doi:10.1029/2010JD014352, 2010.

MacKenzie, I. A. and Harwood, R. S.: Middle atmospheric response to a future increase in humidity arising from increased methane abundance, J. Geophys. Res., 109, D02107, doi:10.1029/2003JD003590, 2004.

Maycock, A. C., Keeley, S. P. E., Charlton-Perez, A. J., and DoblasReyes, F. J.: Stratospheric circulation in seasonal forecasting models: implications for seasonal prediction, Clim. Dynam., 36, 309-321, doi:10.1007/s00382-009-0665-x, 2011.

Maycock, A. C., Joshi, M. M., Shine, K. P., and Scaife, A. A.: The circulation response to idealized changes in stratospheric water vapor, J. Climate, 26, 545-561, doi:10.1175/JCLI-D-1200155.1, 2013.

McCormack, J. P., Hoppel, K. W., and Siskind, D. E.: Parameterization of middle atmospheric water vapor photochemistry for high-altitude NWP and data assimilation, Atmos. Chem. Phys., 8, 7519-7532, doi:10.5194/acp-8-7519-2008, 2008.

McFarlane, N. A., Boer, G. J., Blanchet, J.-P., and Lazare, M.: The Canadian Climate Centre second-generation general circulation model and its equilibrium climate, J. Clim., 5, 1013-1044, 1992.

Monge-Sanz, B. M.: Stratospheric Transport and Chemical Parameterisations in ECMWF Analyses: Evaluation and Improvements using a 3-D CTM, Ph.D. thesis, School of Earth and Environment, University of Leeds, Leeds, UK, 2008.

Monge-Sanz, B. M., Chipperfield, M. P., Simmons, A. J., and Uppala, S. M.: Mean age-of-air and transport in a CTM: Comparison of different ECMWF analyses, Geophys. Res. Lett., 34, L04801, doi:10.1029/2006GL028515, 2007.

Monge-Sanz, B. M., Chipperfield, M. P., Cariolle, D., and Feng, W.: Results from a new linear $\mathrm{O} 3$ scheme with embedded heterogeneous chemistry compared with the parent full-chemistry 3-D CTM, Atmos. Chem. Phys., 11, 1227-1242, doi:10.5194/acp-111227-2011, 2011

Monge-Sanz, B. M., Chipperfield, M. P., Dee, D. P., Simmons, A. J., and Uppala, S. M.: Improvements in the stratospheric transport achieved by a CTM with ECMWF (re)analyses: Identifying effects and remaining challenges, Q. J. Roy. Meteor. Soc., 139, 654-673, doi:10.1002/qj.1996, 2012

Morcrette, J.-J., Barker, H., Cole, J., Iacono, M., and Pincus, R.: Impact of a new radiation package, McRad, in the ECMWF Integrated Forecasting System, Mon. Weather Rev., 136, 4773-4798, doi:10.1175/2008MWR2363.1, 2008.

Oikonomou, E. K. and O'Neill, A.: Evaluation of ozone and water vapor fields from the ECMWF reanalysis ERA-40 during 1991-1999 in comparison with UARS satellite and MOZAIC aircraft observations, J. Geophys. Res., 111, D14109, doi:10.1029/2004JD005341, 2006.

Palmer, T. N., Doblas-Reyes, F. J., Weisheimer, A., and Rodwell, M. J.: Toward seamless prediction: calibration of climate change projections using seasonal forecasts, B. Am. Meteor. Soc., 89, 459-470, 2008.

Park, J., Russell, J., L.Gordley, L., Drayson, S. R., Banner, D., McInerney, J., Gunson, M. R., Toon, G., Sen, B., Blavier, J.F., Webster, C., Zipf, E., Erdman, P., Schmidt, U., and Schiller, C.: Validation of Halogen Occultation Experiment $\mathrm{CH}_{4}$ measurements from the UARS, J. Geophys. Res., 101, 10217-10240, 1996.

Ploeger, F., Fueglistaler, S., Grooß, J.-U., Günther, G., Konopka, P., Liu, Y., Müller, R., Ravegnani, F., Schiller, C., Ulanovski, A., and Riese, M.: Insight from ozone and water vapour on transport in the tropical tropopause layer (TTL), Atmos. Chem. Phys., 11, 407-419, doi:10.5194/acp-11-407-2011, 2011.

Ramanathan, V. and Dickinson, R.: The role of stratospheric ozone in the zonal and seasonal radiative energy balance of the Earthtroposphere system, J. Atmos. Sci., 36, 1084-1104, 1979.

Randel, W., Wu, F., Oltmans, S. J., Rosenlof, K., and Nedoluha, G. E.: Interannual Changes of Stratospheric Water Vapor and Correlations with Tropical Tropopause Temperatures, J. Atmos. Sci., 61, 2133-2148, 2004. 
Rap, A., Forster, P. M., Jones, A., Boucher, O., Haywood, J. M., Bellouin, N., and De Leon, R. R.: Parameterization of contrails in the UK Met Office Climate Model, J. Geophys. Res., 115, D10205, doi:10.1029/2009JD012443, 2010.

Ravishankara, A. R.: Water vapor in the lower stratosphere, Science, 337, 809-810, doi:10.1126/science.1227004, 2012.

Riese, M., Ploeger, F., Rap, A., Vogel, B., Konopka, P., Dameris, M., and Forster, P.: Impact of uncertainties in atmospheric UTLS composition and related radiative effects, J. Geophys. Res., 117, D10205, doi:10.129/2012JD017751, 2012.

Rossow, W. and Schiffer, R.: Advances in understanding clouds from ISCCP, B. Am. Meteorol. Soc., 80, 2261-2288, 1999.

Russell, J. M., Gordley, L. L., Park, J. H., Drayson, S. R., Hesketh, W. D., Cicerone, R. J., Tuck, A. F., Frederick, J. E., Harries, J. E., and Crutzen, P. J.: The Halogen Occultation Experiment, J. Geophys. Res., 98, 10777-10797, 1993.

Scaife, A., Spangehl, T., Fereday, D., Cubasch, U., Langematz, U., Akiyoshi, H., Bekki, S., Braesicke, P., Butchart, N., Chipperfield, M., Gettelman, A., Hardiman, S., Rozanov, M. M. E., and Shepherd, T.: Climate change projections and stratosphere-troposphere interaction, Climate Dyn., 38, 2089 2097, doi:10.1007/s00382-011-1080-7, 2012.

Schmidt, G., Ruedy, R., Hansen, J., Aleinov, I., Bell, N., Bauer, M., Bauer, S., Cairns, B., Canuto, V., Cheng, Y., Del Genio, A., Faluvegi, G., Friend, A., Hall, T., Hu, Y., Kelley, M., Kiang, N., Koch, D., Lacis, A., Lerner, J., Lo, K., Miller, R., Nazarenko, L., Oinas, V., Perlwitz, J., Perlwitz, J., Rind, D., Romanou, A., Russell, G., Sato, M., Shindell, D., Stone, P., Sun, S., Tausnev, N., Thresher, D., and Yao, M.-S.: Present day atmospheric simulations using GISS Model: Comparison to in-situ, satellite and reanalysis data, J. Climate, 19, 153-192, 2006.
Simmons, A. J., Untch, A., Jakob, C., Kållberg, P., and Undén, P.: Stratospheric water vapour and tropical tropopause temperatures in ECMWF analyses and multi-year simulations, Q. J. Roy. Meteorol. Soc., 125, 353-386, 1999.

Solomon, S., Rosenlof, K. H., Portmann, R. W., Daniel, J. S., Davis, S. M., Sanford, T. J., and Plattner, G.-K.: Contributions of stratospheric water vapor to decadal changes in the rate of global warming, Science, 327, 1219-1223, 2010.

Tegtmeier, S., Krüger, K., Wohltmann, I., Schoellhammer, K., and Rex, M.: Variations of the residual circulation in the Northern Hemispheric winter,, J. Geophys. Res., 113, D16109, doi:10.1029/2007JD009518, 2008.

Telford, P. J., Braesicke, P., Morgenstern, O., and Pyle, J. A.: Technical Note: Description and assessment of a nudged version of the new dynamics Unified Model, Atmos. Chem. Phys., 8, 17011712, doi:10.5194/acp-8-1701-2008, 2008.

Uppala, S. M., Kållberg, P. W., Simmons, A. J., Andrae, U., Bechtold, V. D. C., Fiorino, M., Gibson, J. K., Haseler, J., Hernandez, A., Kelly, G. A., Li, X., Onogi, K., Saarinen, S., Sokka, N., Allan, R. P., Andersson, E., Arpe, K., Balmaseda, M. A., Beljaars, A. C. M., Berg, L. V. D., Bidlot, J., Bormann, N., Caires, S., Chevallier, F., Dethof, A., Dragosavac, M., Fisher, M., Fuentes, M., Hagemann, S., Hólm, E., Hoskins, B. J., Isaksen, L., Janssen, P. A. E. M., Jenne, R., McNally, A. P., Mahfouf, J.-F., Morcrette, J.-J., Rayner, N. A., Saunders, R. W., Simon, P., Sterl, A., Trenberth, K. E., Untch, A., Vasiljevic, D., Viterbo, P., and Woollen, J.: The ERA-40 Re-analysis, Q. J. Roy. Meteorol. Soc., 131, 2961-3012, doi:10.1256/qj.04.176, 2005.

van Aalst, M. K., van den Broek, M. M. P., Bregman, A., Brühl, C., Steil, B., Toon, G. C., Garcelon, S., Hansford, G. M., Jones, R. L., Gardiner, T. D., Roelofs, G. J., Lelieveld, J., and Crutzen, P.: Trace gas transport in the 1999/2000 Arctic winter: comparison of nudged GCM runs with observations, Atmos. Chem. Phys., 4, 81-93, doi:10.5194/acp-4-81-2004, 2004. 